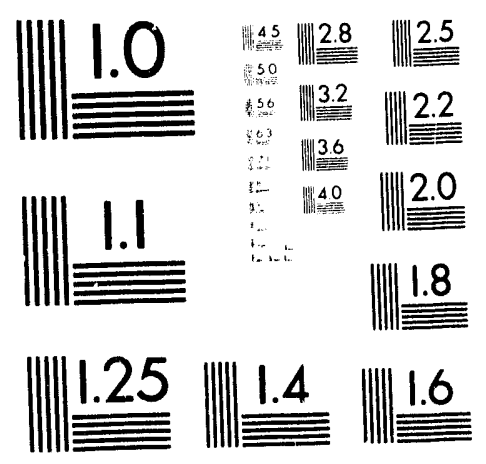



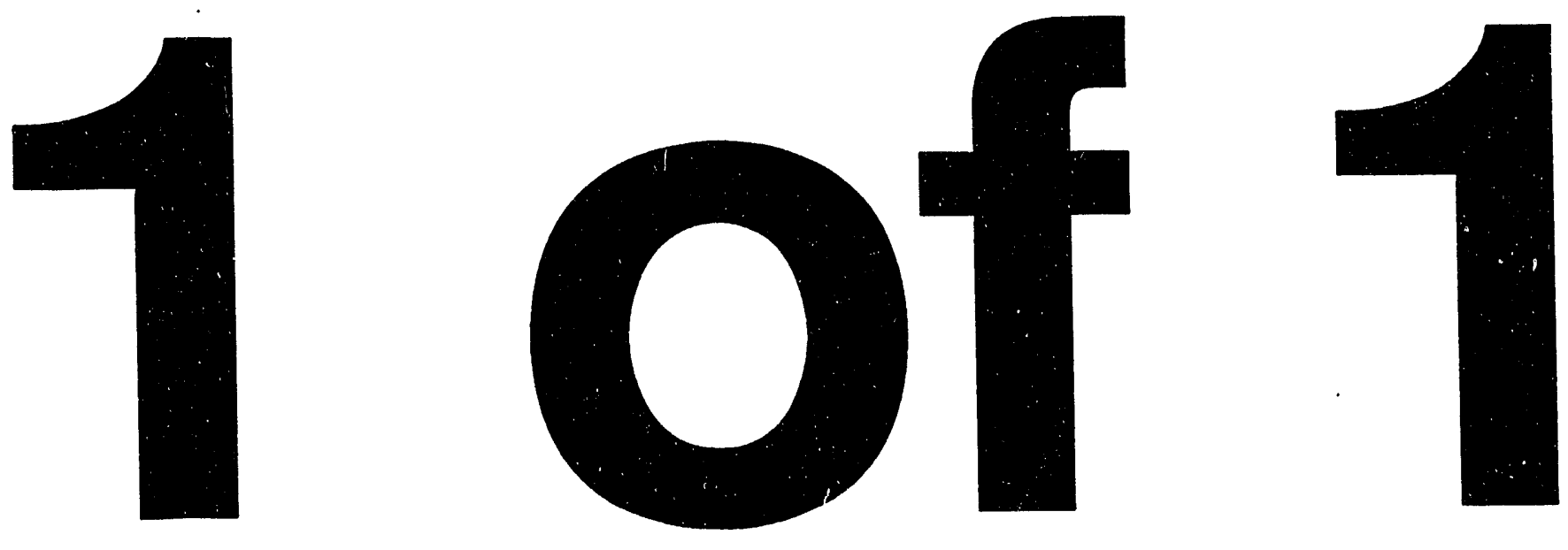
Conf-930443--1

UCRL-JC-112273

PREPRINT

\title{
Global Emissions and Models of Photochemically Active Compounds
}

\author{
J. E. Penner \\ C. S. Atherton \\ T. E. Graedel
}

This paper was prepared for submittal to the Global Atmospheric-Biospheric Chemistry: The

First IGAC Scientific Conference

Eilat, Israel

April 18-22, 1993

May 20, 1993

This is a preprint of a paper intended for publication in a journal or proceedings. Since changes may be made before publication, this preprint is made available with the understanding that it will not be cited or reproduced without the permission of the author.

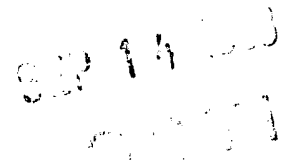




\section{DISCLAIMER}

This document was prepared as an account of work sponsored by an agency of the United States Government. Neither the United States Government nor the University of California nor any of their employees, makes any warranty, express or implied, or assumes any legal liability or responsibility for the accuracy, completeness, or usefulness of any information, apparatus, product, or pro .ss disclosed, or represents that its use would not infringe privately owned rights. Reference herein to any specific commercial products, process, or service by trade name, trademark, manufacturer, or otherwise, does not necessarily constitute or imply its endorsement, recommendation, or favoring by the United States Government or the University of California. The views and opinions of authurs expressed herein do not necessariiy state or reflect those of the United States Government or the University of California, and shall not be used for advertising or product endorsement purposes. 


\title{
Global Emissions and Models of Photochemically Active Compounds
}

\author{
J. E. Penner ${ }^{a}$, C. S. Atherton ${ }^{a}$ and T. E. Graedel ${ }^{b}$ \\ ${ }^{a}$ Atmospheric and Geophysical Sciences Division \\ I awrence Livermore National Laboratory \\ P.O. Box 808 \\ Livermore, California 94550 \\ $\mathrm{b}_{\text {AT\& }} \mathrm{T}$ Bell Laboratories \\ 600 Mountain Avenue \\ P.O. Box 636 \\ Murray Hill, New Jersey, 07974
}

\begin{abstract}
Anthropogenic emissions from industrial activity, fossil fuel combustion, and biomass buming are now known to be large enough (relative to natural sources) to perturb the chemistry of vast regions of the troposphere. A goal of the IGAC Global Emissions Inventory Activity (GEIA) is to provide authoritative and reliable emissions inventories on a $1^{\circ} \times 1^{\circ}$ grid. When combined with atmospheric photochemical models, these high quality emissions inventories may be used to predict the concentrations of major photochemical products. Comparison of model results with measurements of pertinent species allows us to understand whether there are major shortcomings in our understanding of tropospheric photochemistry, the budgets and transport of trace species, and their effects in the atmosphere. Through this activity, we are building the capability to make confident predictions of the future consequerces of anthropogenic emissions. This paper compares IGAC recommended emissions inventories for reactive nitrogen and sulfur dioxide to those that have been in use previcusly. We also present results from the three-dimensional LLNL atmospheric chemistry model that show how emissions of anthropogenic nitrogen oxides might potentially affect tropospheric ozone and $\mathrm{OH}$ concentrations and how emissions of anthropogenic sulfur increase sulfate aerosol loadings.
\end{abstract}

\section{Introduction.}

Anthropogenic emissions of nitrogen oxides $\left(\mathrm{NO}_{\mathrm{x}}\right)$ and sulfur dioxide $\left(\mathrm{SO}_{2}\right)$ from fossil combustion, industrial activity, and from biomass burning are now known to be large enough (relative to natural sources) to perturb the chemistry of vast regions of the troposphere. A goal of the IGAC Global Emissions Inventory Activity (GEIA) is to provide authoritative and reliable emissions inventories on a $1^{\circ} \times 1^{\circ}$ grid. When combined with atmospheric photochemical models, these high quality emissions inventories may be used to predict the concentrations of major photochemical products. Then, comparison of model results with measurements allows us to understand whether there are major shortcomings in our understanding of tropospheric photochemistry, the budgets and transport of trace species, and their effects in the atmosphere. Through this activity, we are building the capability to make confident predictions of the future consequences of anthropogenic emissions.

Two issues have received considerable attention with regard to the potential role of changing anthropogenic emissions to global tropospheric photochemistry. The first issue concerns the oxidizing capacity of the atmosphere and our potential to change this capacity through emissions of methane $\left(\mathrm{CH}_{4}\right)$, nitrogen oxides $\left(\mathrm{NO}_{\mathrm{x}}\right)$, carbon monoxide $(\mathrm{CO})$, and non-methane hydrocarbons (NMHCs). The oxidizing capacity of the atmosphere is determined mainly by the concentration of hydroxyl $(\mathrm{OH})$, although ozone $\left(\mathrm{O}_{3}\right)$ and peroxide $\left(\mathrm{H}_{2} \mathrm{O}_{2}\right)$ also play important roles. The hydroxyl radical reacts with a suite of species (see Table 1), initiating photochemical reaction sequences that eventually lead to non-reactive products (e.g. $\mathrm{CO}_{2}$ ) or to products that are removed by precipitation and dry deposition. If the $\mathrm{OH}$ concentration is globally decreased, the concentrations of gases removed by reaction with OH may increase even with no change in their sources. Hydroxyl radical formation is 
initiated by photolysis of $\mathrm{O}_{3}$ which produces $\mathrm{O}\left({ }^{1} \mathrm{D}\right.$ ) (at wavelengths shorter than about 310 $\mathrm{nm}) . \mathrm{O}\left({ }^{1} \mathrm{D}\right)$ reacts with $\mathrm{H}_{2} \mathrm{O}$ to form two hydroxyl radicals. Since the concentration of $\mathrm{OH}$ in the background atmosphere is mainly determined by the concentrations of $\mathrm{CO}, \mathrm{CH}_{4}, \mathrm{NO}_{\mathrm{x}}$, $\mathrm{O}_{3}$ and $\mathrm{H}_{2} \mathrm{O}$, it is important to quantify the anthropogenic (and natural) emissions of these species to determine their effects on $\mathrm{O}_{3}$ and $\mathrm{OH}$. Anthropogenic emissions of each are tied to industrialization. Increases in $\mathrm{NO}_{\mathrm{x}}$ emissions are particularly important in changing oxidant concentrations because the local concentration of $\mathrm{NO}_{\mathrm{x}}$ determines whether photochemical sequences lead to net $\mathrm{O}_{3} / \mathrm{OH}$ increases or decreases in these species (Penner, 1989; Crutzen and Zimmerman, 1991). Besides its role as an oxidant, changes to tropospheric ozone are of interest because of its role in $\mathrm{OH}$ chemistry and because it acts as a greenhouse gas and has deleterious health and ecosystem effects (e.g. Fishman et al., 1979; Tilton, 1989).

Table 1. Species which are removed or oxidized by reaction with $\mathrm{OH}$.

\begin{tabular}{|c|c|}
\hline Species & Importance \\
\hline $\mathrm{CH}_{4}$ & $\begin{array}{l}\text { Greenhouse gas; Affects tropospheric } \mathrm{O}_{3} \text { and } \mathrm{OH} \text { : Affects stratospheric } \\
\mathrm{O}_{3}\end{array}$ \\
\hline $\mathrm{CO}$ & Urban pollutant; Affects tropospheric $\mathrm{O}_{3}$ and $\mathrm{OH}$ cycles \\
\hline $\begin{array}{l}\mathrm{CH}_{3} \mathrm{CCl}_{3} \\
\mathrm{CH}_{3} \mathrm{Br} \\
\mathrm{CH}_{3} \mathrm{Cl}\end{array}$ & $\begin{array}{l}\text { Greenhouse gases; Release chlorine or bromine in stratosphere which } \\
\text { destroys } \mathrm{O}_{3}\end{array}$ \\
\hline HCFC's & $\begin{array}{l}\text { Greenhouse gases (Hydrochlorofluorocarbons); Replacements for } \\
\text { CFC's which release chlorine in the stratosphere and destroy } \mathrm{O}_{3}\end{array}$ \\
\hline NMHCs & $\begin{array}{l}\text { Urban pollutants; Enhance tropospheric } \mathrm{O}_{3} \text { in high } \mathrm{NO}_{x} \text { areas; Sink for } \\
\text { tropospheric } \mathrm{OH}\end{array}$ \\
\hline $\begin{array}{l}\mathrm{DMS} \\
\mathrm{H}_{2} \mathrm{~S} \\
\mathrm{SO}_{2}\end{array}$ & $\begin{array}{l}\text { Form sulfate aerosols which contribute to acid rain and reflect solar } \\
\text { radiation; Form CCN which alter cloud properties and cool the climate }\end{array}$ \\
\hline
\end{tabular}

The second major issue for tropospheric chemistry which has emerged from a consideration of changing anthropogenic emissions concerns the formation of anthropogenic aerosols and their potential to mask part of the warming expected from greenhouse gas emissions. Anthropogenic aerosols are composed of a variety of aerosol types (e.g. watersoluble inorganic species, organic condensed species, elemental or black carbon, and mineral dust), but the best-quantified and probably the largest component of the anthropogenic aerosol is that derived through photochemical interactions of anthropogenic $\mathrm{SO}_{2}$ emissions (Charlson et al., 1992). Global average climate forcing through direct reflection of solar radiation by anthropogenic sulfate aerosols may range from -0.3 to $-1.1 \mathrm{Wm}^{-2}$ (Penner, et al., 1993). This forcing varies regionally and acts to locally mask anthropogenic greenhouse gas forcing. Because the magnitude of the calculated forcing varies depending on the underlying surface albedo, it is important to correctly estimate the rate of the photochemical processes which convert $\mathrm{SO}_{2}$ to $\mathrm{SO}_{4}=$ as the emissions of $\mathrm{SO}_{2}$ are carried from source regions over areas with high albedo to ocean areas with low albedo. Because these processes are tied to the oxidizing capacity of the atmosphere (through the gas phase reaction of $\mathrm{OH}$ with $\mathrm{SO}_{2}$ and through the aqueous phase reactions of $\mathrm{H}_{2} \mathrm{O}_{2}$ and $\mathrm{O}_{3}$ with sulfur in solution), anthropogenic emissions of both $\mathrm{NO}_{x}$ and $\mathrm{SO}_{2}$ (as well as emissions of $\mathrm{CH}_{4}$ and $\mathrm{CO}$ ) are needed to accurately calculate the climate forcing from sulfate aerosols.

In this paper, we first describe the emissions inventories under development through the IGAC/GEIA for anthropogenic $\mathrm{NO}_{\mathrm{x}}$ and for anthropogenic $\mathrm{SO}_{2}$, comparing these to previously developed inventories. Then, the effects of anthropogenic $\mathrm{NO}_{\mathrm{x}}$ and $\mathrm{SO}_{2}$ emissions are estimated using the LLNL three-dimensional tropospheric photochemical 
model. While we have much more to learn in order to quantify the natural sources of sulfur and the nitrogen oxides, model studies in combination with comparison to measurements can be used diagnose whether our understanding of the sources of these trace gases together with their transport, removal and photochemical processing in the atmosphere is adequate.

\section{IGAC/GEIA Inventories for $\mathrm{NO}_{\mathbf{x}}$ and $\mathrm{SO}_{2}$.}

The developing GEIA global inventories for anthropogenic $\mathrm{SO}_{2}$ and $\mathrm{NO}_{x}$ have as a default a 1985 country-level inventory of fuel combustion emissions compiled by J. Dignon following techniques described in Dignon (1992). These emissions were allocated to a $1^{\circ} \times 1^{\circ}$ grid on the basis of population distributions and statistical relationships between fossil fuel use and emissions (Dignon and Hameed, 1985). Where available the Dignon inventories have been replaced by 1985 regional and national inventories. In some cases the regional and national inventories also supply information on area and point sources such as motor vehicle miles travelled or smelter location and activity. The inventories from which information is being incorporated are as follows: Europe, inventory of the European Monitoring and Evaluation Programme (Sandnes and Styve, 1992); North America, inventory of the National Acid Precipitation Assessment Program (Saeger et al., 1989; Wagner et al., 1986); Southeast Asia, inventory of M. Kato and H. Akimoto (Kato and Akimoto, 1992; Kato, N. and H. Akimoto; 1993); Former Soviet Union, inventory of J. Pacyna in consultation with FSU scientists (Pacyna, 1992); Australia, inventory of F. Carnovale (Carnovale, 1992). The GEIA team for the integrated inventories consisted of C. Benkovitz, J. Dignon, T. Graedel, J. Pacyna. T. Scholtz, L. Tarrason, and E. Voldner. While compilation of these new inventories is not yet complete, here we compare the updated GEIA inventories for North America, Europe, Asia, and Australia with those published by Dignon (1992) for 1980 for $\mathrm{NO}_{\mathrm{x}}$ and with those published by Spiro et al. (1992) and Benkovitz (1982) for $\approx 1980$ for $\mathrm{SO}_{2}$. These latter inventories have served as the basis for previous LLNL model runs to assess the importance of anthropogenic emissions of $\mathrm{NO}_{x}$ and $\mathrm{SO}_{2}$ to tropospheric oxidant concentrations and to anthropogenic sulfate aerosol forcing of climate, respectively, and are used in the present study for those areas where IGAC inventories are not yet complete.

Figure la presents the 1985 IGAC inventory for $\mathrm{NO}_{\mathbf{x}}$ for North America and Figure Ib shows differences from the 1980 inventory by Dignon (1992). North American emissions are smaller by at least a factor of 0.3 over much of the area, but larger by more than a factor of 1.5 in others. Summed over the entire area, the emissions from the two inventories are similar, however $(6.2$ and $6.7 \mathrm{Tg} \mathrm{N} \mathrm{yr}-1$ for IGAC and Dignon, respectively). Figure 2a presents the 1985 IGAC inventory for Europe while Figure 2b shows differences between the IGAC inventory and that of Dignon. As was the case in North America, this comparison demonstrates a redistribution of emissions, but overall emissions are again similar between the two inventories $\left(5.5 \mathrm{Tg} \mathrm{N}_{\mathrm{yr}} \mathrm{r}^{-1}\right.$ and $5.4 \mathrm{Tg} \mathrm{N} \mathrm{yr}^{-1}$, respectively). The differences noted in these figures may not cause large differences in photochemical response of the global LLNL model, because the resolution of the emissions used in the current version is prescribed by the resolution of the meteorological fields (which is currently $\sim 4.5^{\circ} \times 7.5^{\circ}$ ). These emissions updates should be important to developing models that have significantly higher resolution, however. We note that in the new inventory, Asian emissions (not shown) are significantly larger than those from Dignon (1992), except in Japan, where they have decreased by between 10 and $30 \%$.

Overall emissions in Asia increased from 3.6 to $4.1 \mathrm{Tg} \mathrm{N} \mathrm{yr}^{1}$. Total emissions from Australia are also larger in the new inventory, having increased from $0.16 \mathrm{Tg} \mathrm{N}_{\mathrm{yr}}{ }^{-1}$ to $0.24 \mathrm{Tg} \mathrm{N} \mathrm{yr}^{-1}$. As in other cases, however, the redistribution of emissions in the new inventory means that emissions actually decrease in some regions while increasing in others. 


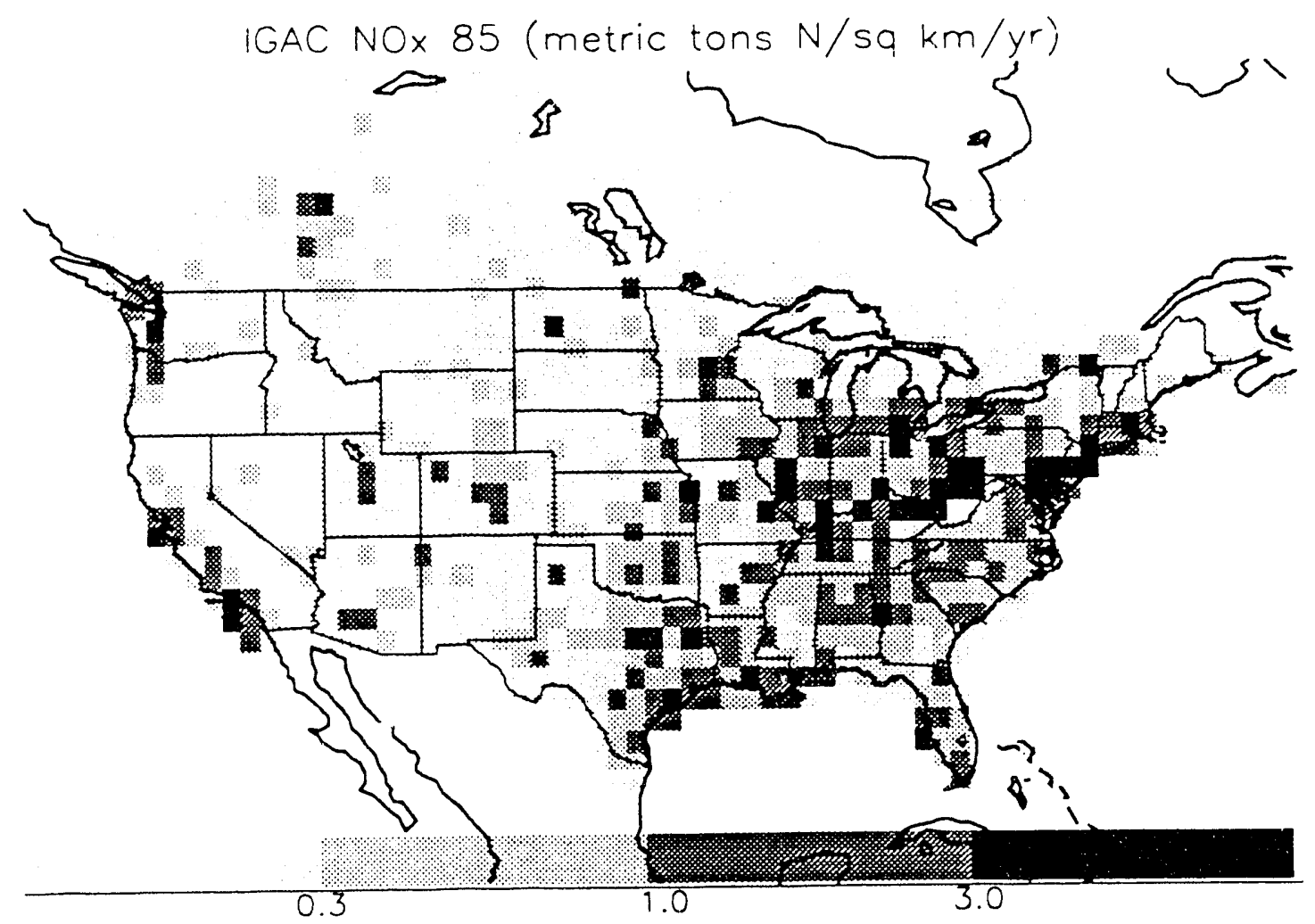

Figure 1a. The IGAC GEIA NO $\mathrm{N}_{\mathrm{x}}$ inventory for North America. The lightest shade shows areas with less than 0.3 tons $\mathrm{N} \mathrm{km}^{-2} \mathrm{yr}^{2}$ and increasing darkness of shade delineates areas where emissions range from 0.3 to 1.0 tons $\mathrm{N} \mathrm{km}^{-2} \mathrm{yr}^{-2}$, from 1.0 to 3.0 tons $\mathrm{N} \mathrm{km}^{-2} \mathrm{yr}^{2}$, and are greater that 3.0 tons $\mathrm{N} \mathrm{km}^{-2} \mathrm{yr}^{-2}$, respectively.

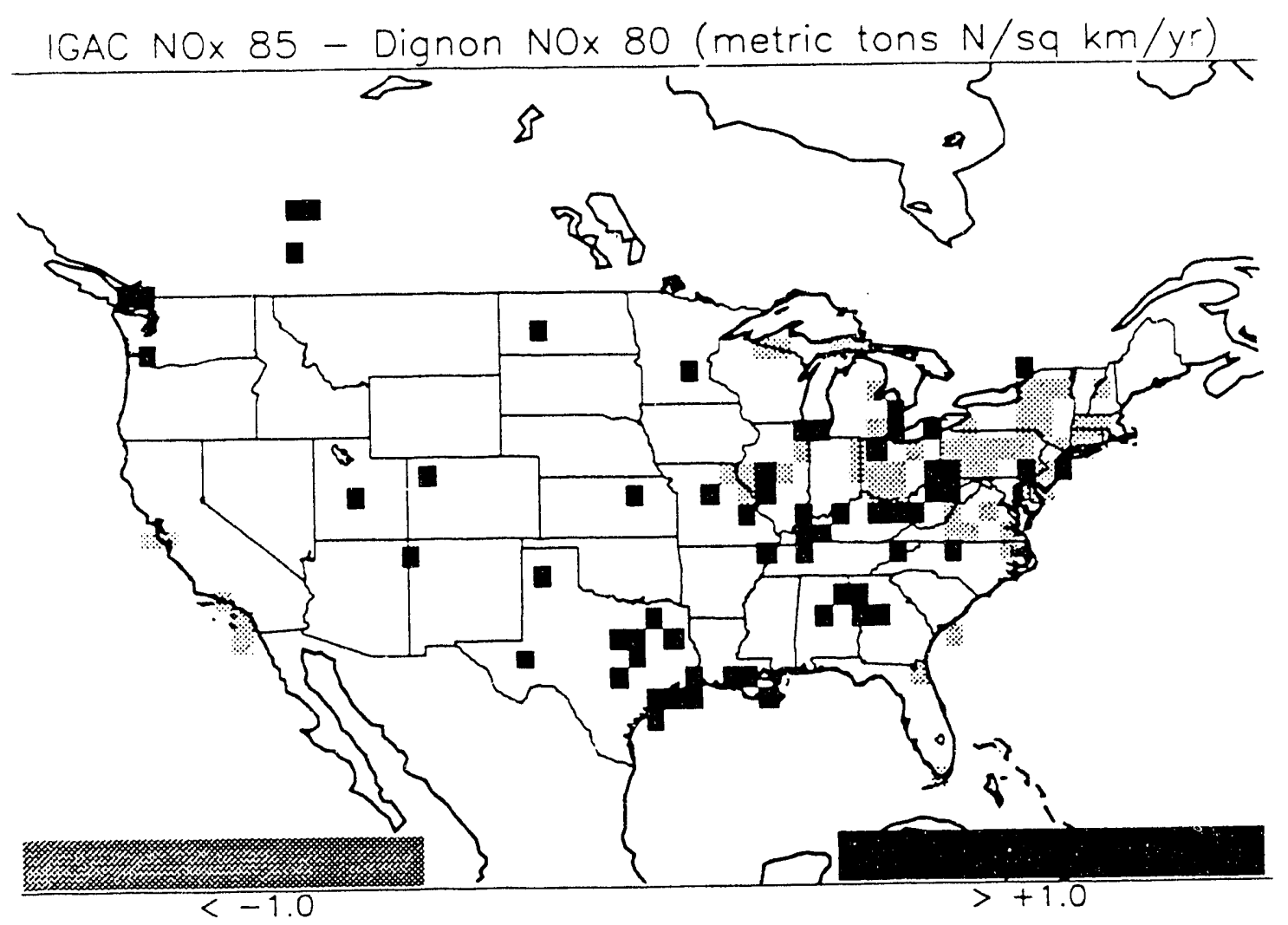

Figure 1b. Areas in North America where the difference between the IGAC GEIA inventory for $\mathrm{NO}_{\mathrm{x}}$ and that developed by Dignon (1992) is greater than 1 ton $\mathrm{N} \mathrm{km}^{-2} \mathrm{yr}$ (black shade) or less than -1 ton $\mathrm{N} \mathrm{km}^{-2} \mathrm{yr}^{-1}$ (lighter shade). 


\section{IGAC NOX 85 (metric tons $\mathrm{N} / \mathrm{sq} \mathrm{km} / \mathrm{yr}$ )}

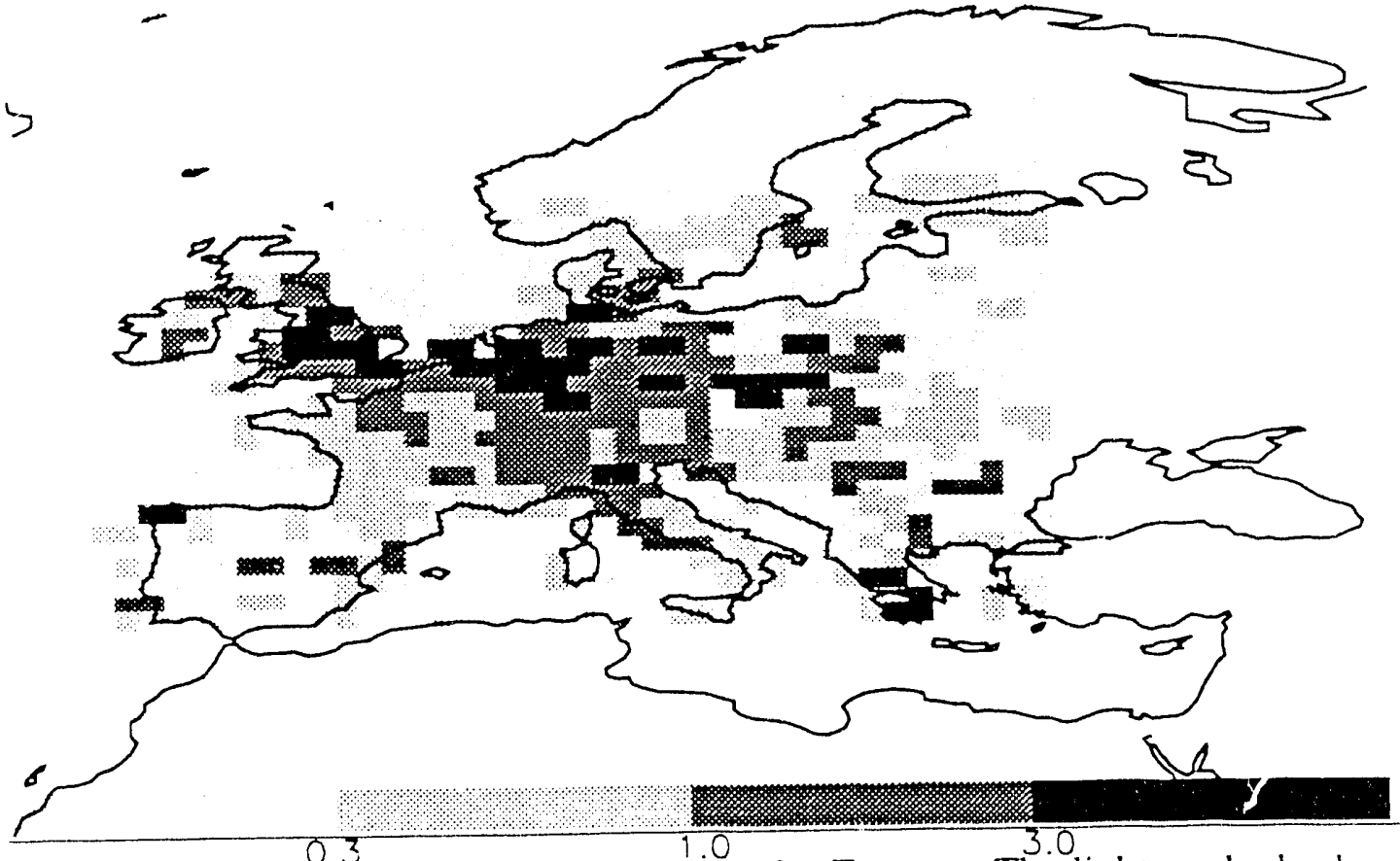

Figure 2a. The IGAC GEIA NO inventory for Europe. The lightest shade shows areas with less than 0.3 tons $\mathrm{N} \mathrm{km}^{-2} \mathrm{yr}^{2}$ and increasing darkness of shade delineates areas where emissions range from 0.3 to 1.0 tons $\mathrm{N} \mathrm{km}^{-2} \mathrm{yr}^{-2}$, from 1.0 to 3.0 tons $\mathrm{N}$ $\mathrm{km}^{-2} \mathrm{yr}^{-2}$, and are greater that 3.0 tons $\mathrm{N} \mathrm{km}^{-2} \mathrm{yr}^{2}$, respectively.

\section{IGAC NOX 85 - Dignon NOx 80 (metric tons $\mathrm{N} / \mathrm{sq} \mathrm{h} . \mathrm{m} / \mathrm{yr}$ )}

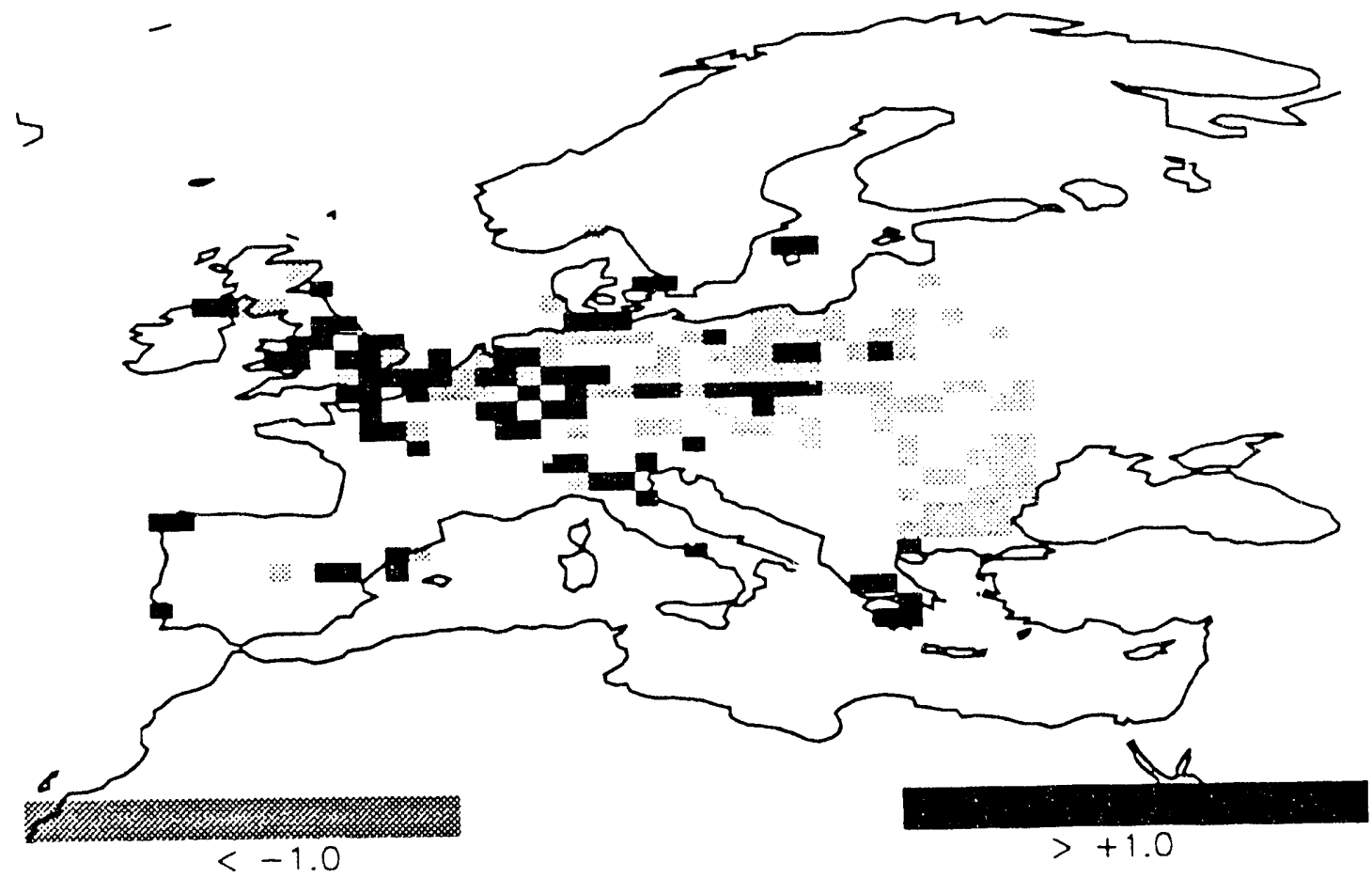

Figure 2b. Areas in Europe where the difference between the IGAC GEIA inventory for $\mathrm{NO}_{\mathrm{x}}$ and that developed by Dignon (1992) is greater than 1 ton $\mathrm{N} \mathrm{km}^{-2} \mathrm{yr}^{-1}$ (black shade) or less than -1 ton $\mathrm{N} \mathrm{km}^{-2} \mathrm{yr}^{-1}$ (lighter shade). 
Figures 'ia and 4a present the IGAC SC/2 inventories for North America and Europe, while Figures $3 \mathrm{~b}$ and $4 \mathrm{~b}$ show areas of importint differences between the IGAC inventories and those developed by Benkovitz (1982) for North America and by Spiro et al. (1992) for Europe. In Figure 3b, for $\mathrm{SO}_{2}$, North American emissions in the Benkovitz (1982) inventory refer to calendar year 1975 for area sources and to 1977-1978 for point sources, whereas the IGAC inventory was derived from inventories developed by NAPAP for calendar year 1985 (Saeger et al., 1989). The total $\mathrm{SO}_{2}$ emissions in the Benkovitz (1982) inventory for $=1975$ is similar to that developed by NAPAP for North America for 1980 (Spiro et al., 1992). According to these inventory estimates, emissions of $\mathrm{SO}_{2}$ may have decreased by $25 \%$, from $16 \mathrm{Tg}$ S/yr to $12 \mathrm{Tg} \mathrm{S} / \mathrm{yr}$, over this $\approx 10$ year time period. European emissions in the Spiro et al. (1992) inventory were derived from an OECD inventory (Lubkert and De Tilly, 1989) for 1980, while those in the IGAC inventory were developed by the Cooperative Program for Monitoring and Evaluation of the Long Range Transmission of Air Pollutants in Europe (EMEP) for calendar year 1985 (Sandnes and Styve, 1992). According to these estimates European $\mathrm{SO}_{2}$ emissions may have decreased by $14 \%$, from 21 $\mathrm{Tg} \mathrm{S} / \mathrm{yr}$ to $18 \mathrm{Tg} \mathrm{S} / \mathrm{yr}$, over this 5 year time period. The IGAC inventories for Asia and Australian have also decreased in the new inventory. The new emissions are $13 \mathrm{Tg} \mathrm{S} \mathrm{yr}^{-1}$ and $1.0 \mathrm{Tg} \mathrm{S} \mathrm{yr} r^{-1}$ for Asia and Australia, respectively, smaller than those developed by Spiro et al. (1992) by $13 \%$ and $23 \%$, respectively. The decreases for these regions may reflect differences in methodology rather than real decreases in emissions. Overall, the new inventories imply reduced emissions of approximately $9 \mathrm{Tg} \mathrm{S} / \mathrm{yr}$ (or slightly more than 15\%) from these four regions. It is nut known whether decreased emissions should apply for other areas. Spiro et al. (1992) argue that emissions in the forrier Soviet Union decreased by almost $33 \%$ or $4.1 \mathrm{Tg} \mathrm{S} / \mathrm{yr}$ between 1980 and 1989 (the latter year is represented in their inventory). We note that fossil fuel use in the former Soviet Union increased by more than $27 \%$ from 1980 to 1987 according to the statistics available through the United Nations. Total world wide fossil fuel use increased by almost $13 \%$ over this time period.

\section{LLNL model}

The Lawrence Livermore National Laboratory tropospheric chemistry model (called GRANTOUR, c. f. Walton et al., 1988) was used in conjunction with the Dignon (1992) inventory for anthropogenic $\mathrm{NO}_{\mathrm{x}}$ emissions and the Spiro et al. (1992) inventory for anthropogenic $\mathrm{SO}_{2}$ emissions, but updated in the four regions where quality data for 1985 were made available through Carmen Benkovitz of the GEIA committee. GRANTOUR is a Lagrangian parcel model which may be run either off-line, using the wind and precipitation fields from a general circulation model, or interactively, in a mode that allows alterations of the wind and $\mathrm{f}$ :ecipitation fields consistent with currently calculated species or aerosol concentrations. The model is typically run with 50,000 constant-mass air parcels whose dimensions average $100 \mathrm{mb} \times 330 \mathrm{~km} \times 330 \mathrm{~km}$. The model has been used to study the effects of smoke from a nuclear war on climate (Ghan et al., 1988), the effects of an asteroid impact on climate (Covey et al., 1988), the cycle of reactive nitrogen in the troposphere (Penner et al., 1991), the sulfur cycle in the troposphere (Erickson et al., 1991; Galloway et al., 1992), climate forcing by smoke aerosols produced in biomass burning (Penner, et al., 1991), black carbon aerosol distributions (Penner et al., 1993), and $222 \mathrm{Rn}$ and $210 \mathrm{~Pb}$ distributions (Dignon et al., 1993).

$t$ the present time, the model is normally run in an annual-cycle mode using the winds and precipitation fields from the R15 version of the Livermore/NCAR CCM1 model. The winds from the CCMl model are averaged over a 12-hour time period for use by the LLNL GRANTOUR model. For surface-based sources, trace species are input into the model with a vertical profile that is normally assumed to be constant in mixing ratio in the lowest $100 \mathrm{mb}$. The gas phase reactions of DMS and $\mathrm{SO}_{2}$ with $\mathrm{OH}$ for the model of the sulfur cycle presented below, assumed a background concentration of $\mathrm{OH}$ that was specified according to the latitudenally- and seasonally-varying calculated concentrations from the LLNL 2-dimensional model (see Penner et al., 1991) while in the oxidant model these were calculated based on the reactions given in Tables 2 and 3 below. Additionally, in the oxidant model, $\mathrm{CO}$ concentrations were fixed but varied monthly, with surface concentrations in remote areas 


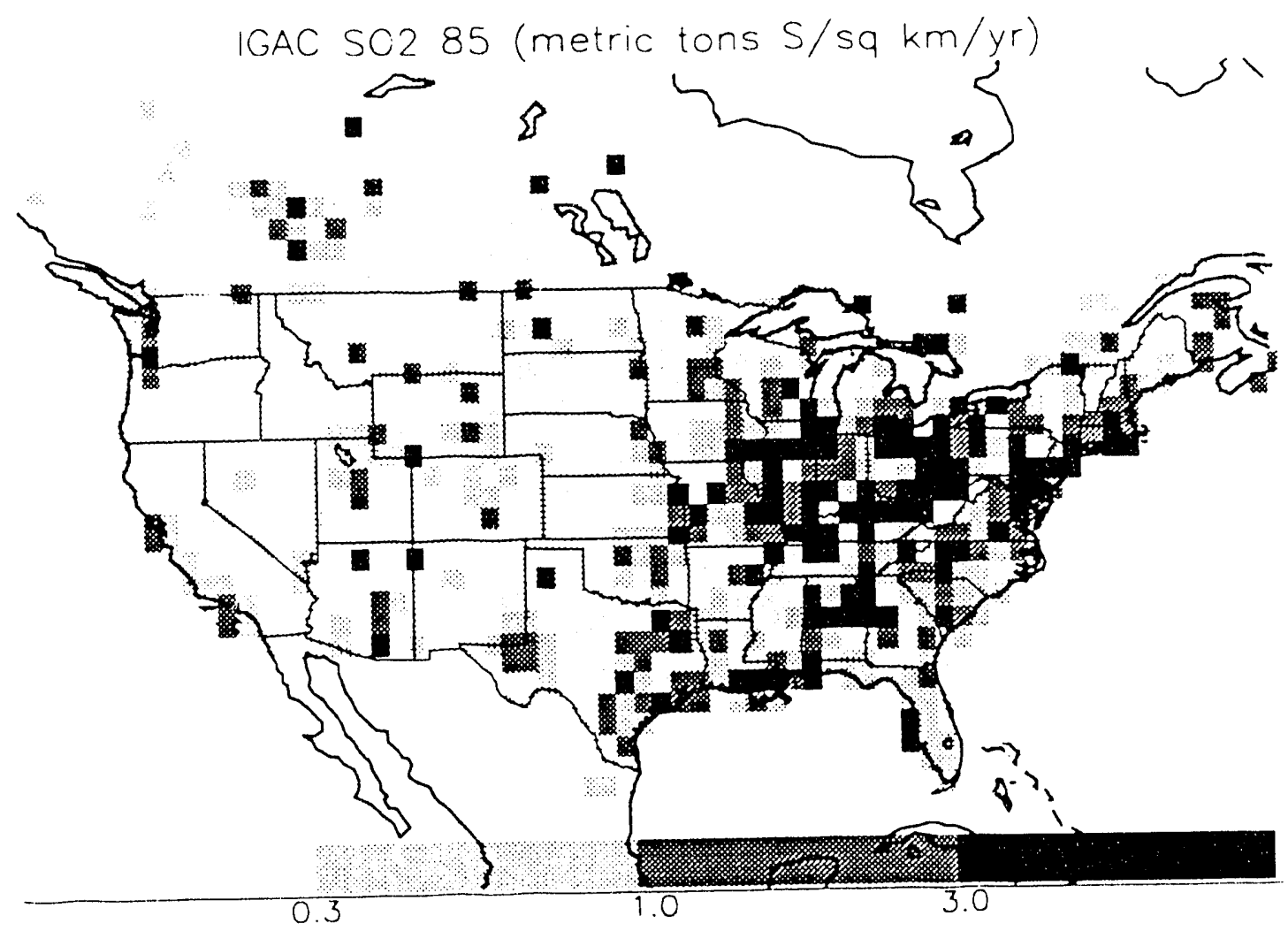

Figure 3a. The IGAC GEIA $\mathrm{SO}_{2}$ inventory for North America. The lightest shade shows areas with less than 0.3 tons $\mathrm{S} \mathrm{km}^{-2} \mathrm{yr}^{-2}$ and increasing darkness of shade delineates areas where emissions range from 0.3 to 1.0 tons $\mathrm{S} \mathrm{km}^{-2} \mathrm{yr}^{-2}$, from 1.0 to 3.0 tons $\mathrm{S} \mathrm{km}^{-2} \mathrm{yr}^{-2}$, and are greater that 3.0 tons $\mathrm{S} \mathrm{km}^{-2} \mathrm{yr}^{-2}$, respectively.

GAC SO2 85 - Benkovitz SO2 (metric tons $\mathrm{S} / \mathrm{sq} \mathrm{km} / \mathrm{yr}$ )

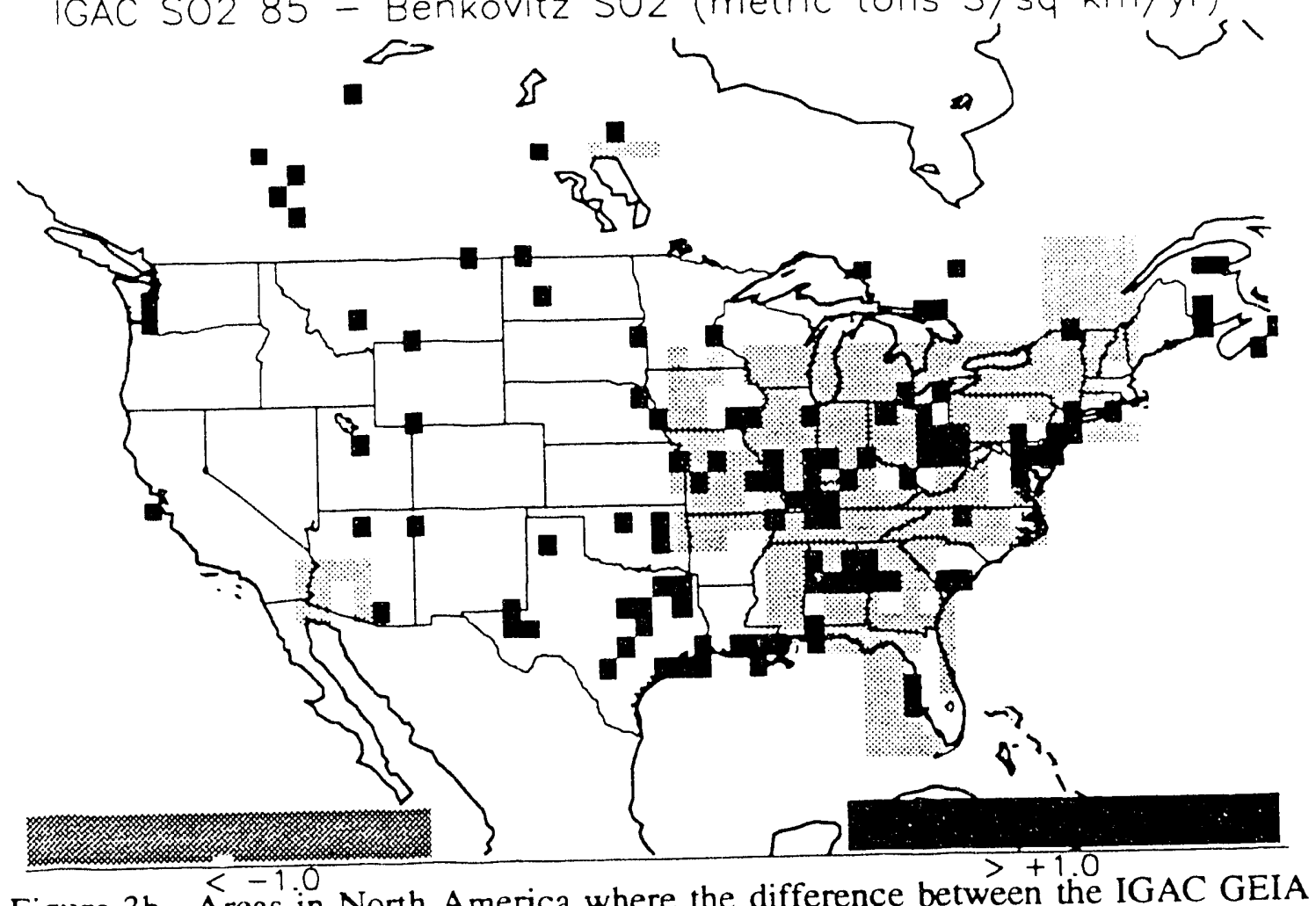

Figure 3b. Areas in North America where the difference between the IGAC GEIA inventory for $\mathrm{SO}_{2}$ and that developed by Benkovitz(1982) is greater than 1 ton $\mathrm{S} \mathrm{km}^{-2}$ $\mathrm{yr}^{-1}$ (black shade) or less than -1 ton $\mathrm{S} \mathrm{km}^{-2} \mathrm{yr}^{-1}$ (lighter shade). 


\section{IGAC SO2 85 (metric tons $\mathrm{S} / \mathrm{sq} \mathrm{km} / \mathrm{yr}$ )}

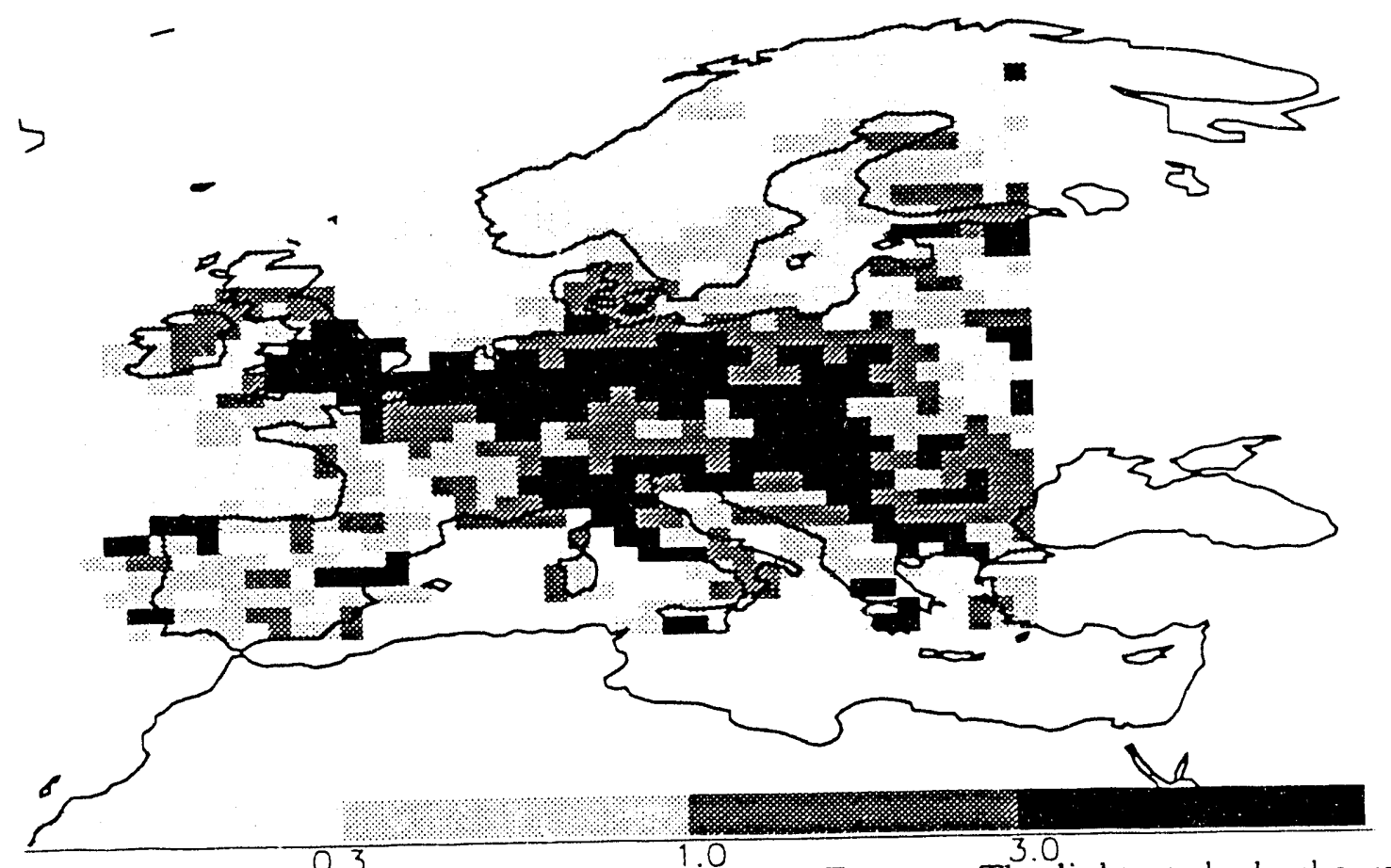

Figure 4a. The IGA ${ }^{3}$ C GEIA SO 2 inventory for Europe. The lightest shade shows areas with less than 0.3 tons $S \mathrm{~km}^{-2} \mathrm{yr}^{2}$ and increasing darkness of shade delineates areas where emissions range from 0.3 to 1.0 tons $\mathrm{S} \mathrm{km}^{-2} \mathrm{yr}^{-2}$, from 1.0 to 3.0 tons $\mathrm{S}$ $\mathrm{km}^{-2} \mathrm{yr}^{2}$, and are greater that 3.0 tons $\mathrm{S} \mathrm{km}^{-2} \mathrm{yr}^{-2}$, respectively.

IGAC SO2 85 - Spiro SO2 (metric tons S/sq km/yr)

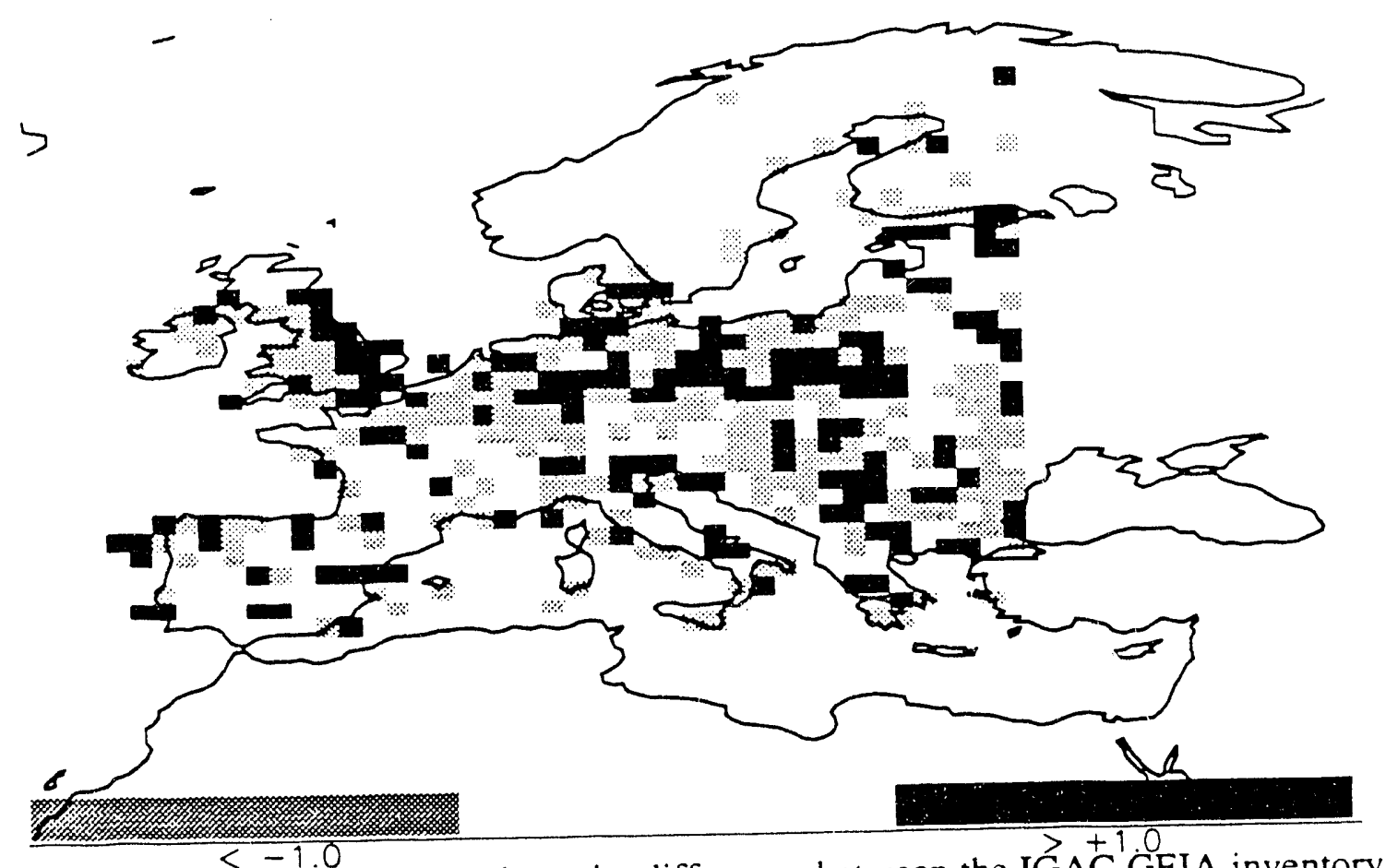

Figure 4b. Areas in Europe where the difference between the IGAC GEIA inventory for $\mathrm{SO}_{2}$ and that developed by Spiro et al. (1992) is greater than 1 ton S km-2 $\mathrm{yr}^{-1}$ (black shade) or less than -1 ton $\mathrm{S} \mathrm{km}^{-2} \mathrm{yr}^{-1}$ (lighter shade). 
taken from xxx and with values increased in grid squares where fossil fuel emissions and biomass burning take place. The increase was proportional to the intensity of these activities in each grid square, with a specified maximum concentration of $\mathbf{x x x} \mathrm{ppb}$. Surface $\mathrm{CH}_{4}$ concentrations were fixed according to the observations of Steele et al. (1987) and for both $\mathrm{CO}$ and $\mathrm{CH}_{4}$ the variation in concentration with altitude followed the predictions of the LLNL 2-D model. In addition, the concentration of $\mathrm{O}_{3}$ above $200 \mathrm{mb}$ was specified on a monthly basis according to results from the LLNL 2-dimensional model scaled to more properly simulate ozone sonde data (Komyhr et al., 1989). The $\mathrm{H}_{2} \mathrm{O}$ concentration varied monthly according to the predicted monthly-averaged concentrations from the climate model. These latter concentrations have been compared to observations by $\mathbf{x x x}$ and are, in general, somewhat low (due to a cold bias in the model), but are not unreasonable. (How low??)

The reaction rate coefficients are given in Table 2 and are consistent with recent recommendations by DeMore et al. (1992) and Atkinson et al. (1992). They were varied monthly according to the average temperature and pressure at each location in the model. Factors which account for the diurnal averaging of reaction rates were taken from the LLNL two-dimensional model as were the photolysis rate coefficients for the reactions in Table 3 (a description of the LLNL two-dimensional model appears in Johnston et al., 1989; Wuebbles and Kinnison, 1989; and Wuebbles et al., 1993). Aqueous reaction of $\mathrm{SO}_{2}$ to form $\mathrm{SO}_{4}=$ in clouds was treated in a simplified manner. This process was assumed to have an average efolding lifetime of 30 hours at $40^{\circ} \mathrm{N}$ at the surface in summer and was scaled, proportional to the square of the locally specified concentration of $\mathrm{OH}$ at other locations. This formulation is a simplified attempt to account for the observed seasonal variations in sulfate concentrations and wet deposition in North America, by assuming that the rate of formation of $\mathrm{SO}_{4}=$ in clouds depends both on the frequency of interception of a cloud by an air parcel (average cloud-free periods vary from 10 to 80 hours (Lelieveld and Crutzen, 1990; 1991) and on the local concentration of $\mathrm{H}_{2} \mathrm{O}_{2}$ (which was assumed to be proportional to square of the specified concentration of $\mathrm{OH}$ ).

In addition to the photochemical reactions in the model, each species may experience deposition if air parcels are in the lowest $100 \mathrm{mb}$. The deposition velocities are set by average observed values but may vary from ocean to land surfaces. In addition, trace species may be scavenged by precipitation with scavenging rates proportional to the amount of precipitation in the model (expressed as $\mathrm{cm} \mathrm{h}^{-1}$ ) and scavenging coefficients set to reproduce measured washout ratios. The values used in the present simulations are shown in Table 4. Other details regarding the model formulation can be found in Walton et al. (1988), Penner et al. (1991), and Atherton (1993). 
Table 2. Reactions and rate coefficients used in the model calculations $\left(\mathrm{cm}^{3} \mathrm{~s}^{-1}\right)$.

Rate coefficient

at ground level

Reaction

and $298^{\circ}$

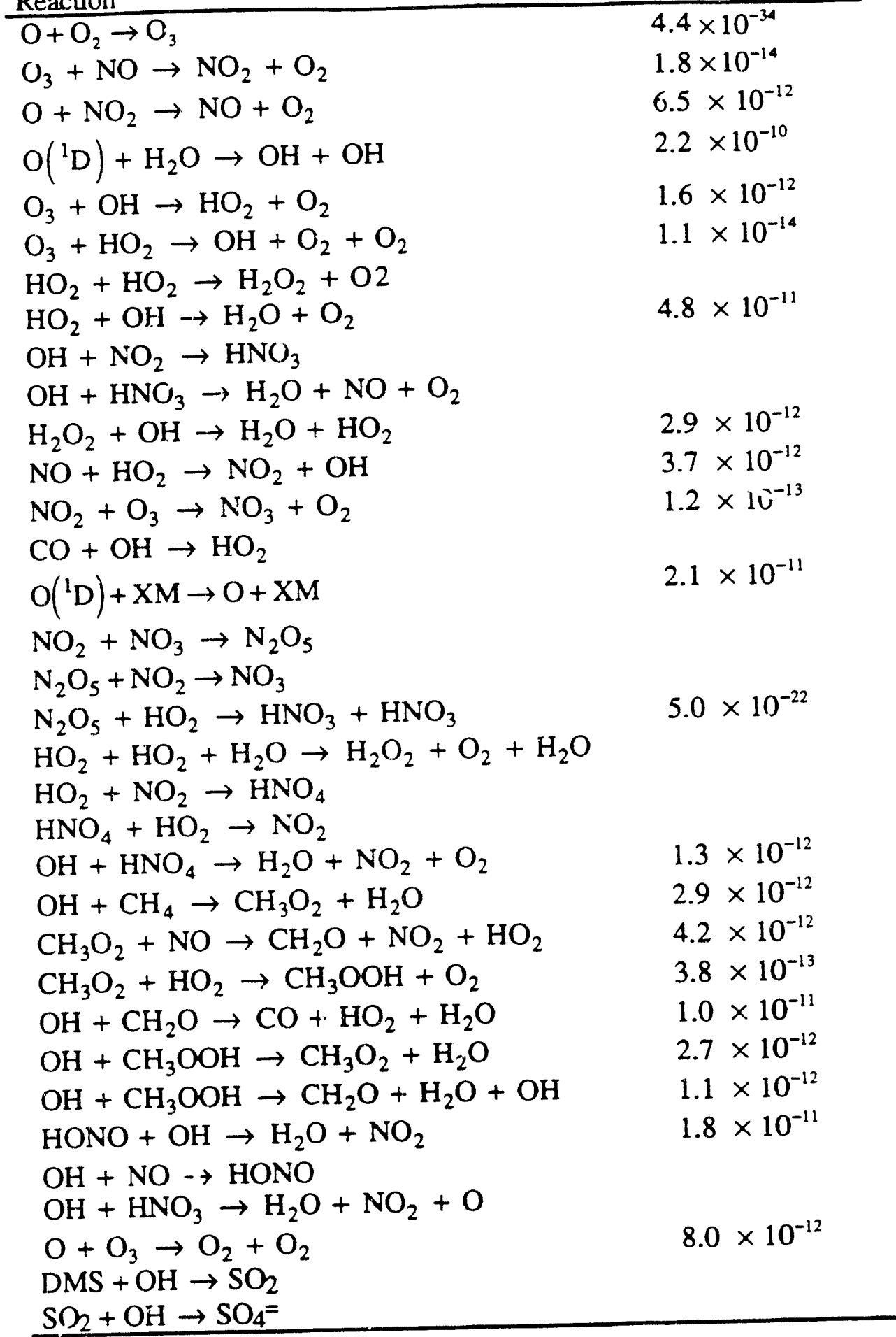


Table 3. Photolysis reactions in the model

$$
\begin{aligned}
& \mathrm{O}_{3} \rightarrow \mathrm{O}+\mathrm{O}_{2} \\
& \mathrm{O}_{3} \rightarrow \mathrm{O}\left({ }^{1} \mathrm{D}\right)+\mathrm{O}_{2} \\
& \mathrm{NO}_{2} \rightarrow \mathrm{NO}+\mathrm{O} \\
& \mathrm{HNO}_{3} \rightarrow \mathrm{OH}+\mathrm{NO}_{2} \\
& \mathrm{H}_{2} \mathrm{O}_{2} \rightarrow \mathrm{CH}+\mathrm{OH} \\
& \mathrm{HO}_{2} \rightarrow \mathrm{OH}+\mathrm{O} \\
& \mathrm{N}_{2} \mathrm{O} 5 \rightarrow \mathrm{NO}_{2}+\mathrm{NO}_{2}+\mathrm{O} \\
& \mathrm{NO}_{3} \rightarrow \mathrm{NO}+\mathrm{O}_{2} \\
& \mathrm{NO}_{3} \rightarrow \mathrm{NO}_{2}+\mathrm{O} \\
& \mathrm{HNO} 4 \rightarrow \mathrm{OH}+\mathrm{NO}+\mathrm{O}_{2} \\
& \mathrm{CH}_{3} \mathrm{OOH} \rightarrow \mathrm{CH}_{2} \mathrm{O}+\mathrm{HO}_{2}+\mathrm{OH} \\
& \mathrm{CH}_{2} \mathrm{O} \rightarrow \mathrm{CO}+\mathrm{HO}_{2}+\mathrm{HO}_{2} \\
& \mathrm{CH}_{2} \mathrm{O} \rightarrow \mathrm{CO} \\
& \mathrm{N}_{2} \mathrm{O} 5 \rightarrow \mathrm{NO}_{2}+\mathrm{NO}+\mathrm{O}_{2} \\
& \mathrm{HNO} 4 \rightarrow \mathrm{OH}+\mathrm{NO}_{2}+\mathrm{O} \\
& \mathrm{HONO} \rightarrow \mathrm{OH}+\mathrm{NO} \\
& \mathrm{O}_{2} \rightarrow \mathrm{O}+\mathrm{O}
\end{aligned}
$$


Table 4. Deposition velocities and precipitation scavenging coefficients used in the modela

\begin{tabular}{|c|c|c|c|}
\hline Species & $\begin{array}{c}\text { Deposition } \\
\text { velocity }\left(\mathrm{cm} \mathrm{s}^{-1}\right) \\
\end{array}$ & $\begin{array}{c}\text { Large-scale } \\
\text { precipitation } \\
\text { scavenging } \\
\text { coefficient }\left(\mathrm{cm} \mathrm{hr}^{-1}\right) \\
\end{array}$ & $\begin{array}{c}\text { Convective } \\
\text { precipitation } \\
\text { scavenging } \\
\text { coefficient }\left(\mathrm{cm} \mathrm{hr}^{-1}\right) \\
\end{array}$ \\
\hline $\mathrm{O}_{3}$ & $\begin{array}{c}0.6 \text { (land) } \\
0.06 \text { (ocean) }\end{array}$ & 0.0 & 0.0 \\
\hline NO & 0.1 & 0.0 & 0.0 \\
\hline $\mathrm{NO}_{2}$ & $\begin{array}{c}0.5 \text { (land) } \\
0.1 \text { (ocean) }\end{array}$ & 0.0 & 0.0 \\
\hline $\mathrm{H}_{2} \mathrm{O}_{2}$ & 1.0 & 2.4 & 4.7 \\
\hline $\mathrm{HNO}_{3}$ & 1.0 & 2.4 & 4.7 \\
\hline $\mathrm{NO}_{3}$ & 0.4 & 0.0 & 0.0 \\
\hline $\mathrm{N}_{2} \mathrm{O}_{5}$ & 0.4 & 1.0 & 2.0 \\
\hline $\mathrm{CH}_{2} \mathrm{O}$ & 0.2 & 2.0 & 4.0 \\
\hline $\mathrm{CH}_{3} \mathrm{OOH}$ & 1.0 & 2.0 & 4.0 \\
\hline HONO & 0.0 & 1.5 & 3.0 \\
\hline $\mathrm{SO}_{2}$ & 0.8 & 0.8 & 1.5 \\
\hline $\mathrm{SO}_{4}=$ & 0.1 & 5.0 & 1.5 \\
\hline
\end{tabular}

These parameters were set to 0.0 for $\mathrm{O}, \mathrm{O}\left({ }^{\mathrm{D}} \mathrm{D}\right), \mathrm{OH}, \mathrm{HO}_{2}, \mathrm{HNO}_{4}, \mathrm{CH}_{3} \mathrm{O}_{2}$, and DMS.

\section{Model prediction of tropospheric sulfate aerosol}

Model calculations of the tropospheric sulfate aerosol abundance require reactive sulfur emissions from five main sources: production of (mainly) dimethyl sulfide (DMS) in the oceans by phytoplankton, volcanic emissions of sulfur dioxide $\left(\mathrm{SO}_{2}\right)$, terrestrial emissions of DMS and hydrogen sulfide $\left(\mathrm{H}_{2} \mathrm{~S}\right)$ from soils, forests and crops, biomass burning emissions of $\mathrm{SO}_{2}$, and fossil fuel and industrial emissions of $\mathrm{SO}_{2}$. Table 5 gives a summary of the magnitude of the reactive sulfur sources that were used in the calculations reported here and the range in possible emissions magnitudes as reported by a number of authors (see Penner, 1993). In all cases, the inventories derived by Spiro et al. (1992) were used, except for the anthropogenic emissions which have been updated as noted above and except for the ocean emissions of DMS. For ocean emissions the inventory from Spiro et al. (1992) was doubled.

As noted above, we expect that as emission inventories evolve and become more accurate, model comparison with data will provide a stringent test of whether the model correctly summarizes the effects of transport, photochemical transformation, and deposition. The adequacy of the current model may be seen by the comparisons presented below.

Figure 5 shows a comparison of the predicted monthly averaged concentrations of $\mathrm{SO}_{4}=$ at selected locations with data summarized by Langner and Rodhe (1991). Note that some of the data appear to be quite reasonably represented (e.g. $\mathrm{SO}_{4}=$ over the Ohio River Valley), while other data are poorly reproduced $\left(\mathrm{SO}_{4}=\right.$ over southern Sweden). Tne 
Table 5. Global sources of reactive sulfur used in the model and an estimate of their possible range ( $\mathrm{Tg} \mathrm{S} / \mathrm{yr}$ ).

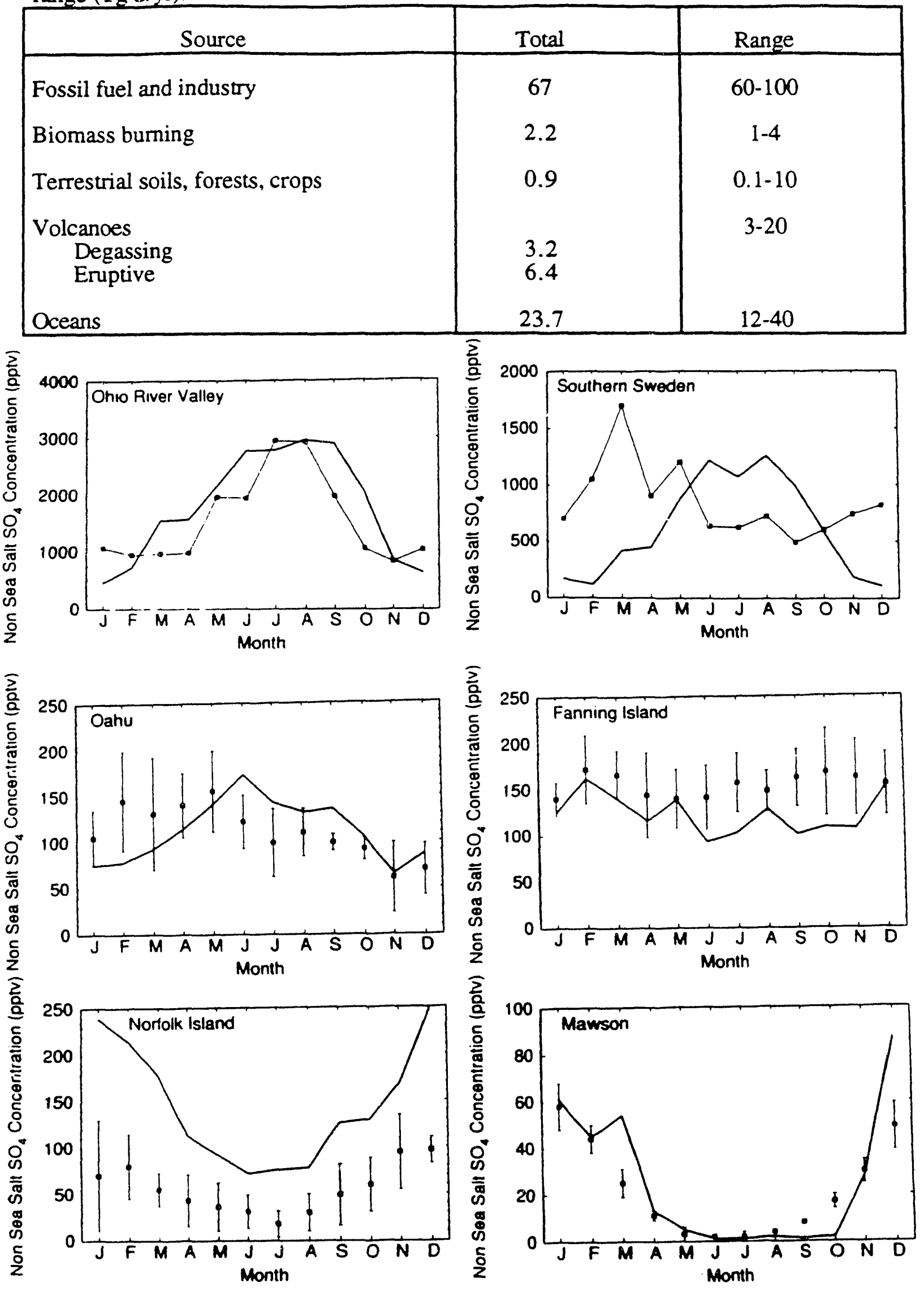

Figure 5. Model calculated (smooth line) and observed (squares) annual cycle of non-sea salt sulfate (in pptv) at selected locations throughout the year. The left scale is in pptv. Otservations have been summarized by Iangner and Rodhe (1991). 
seasonal changes seen for $\mathrm{SO}_{4}=$ are mainly a result of the seasonality of the $\mathrm{SO}_{4}=$ source. Both the source derived from reaction of $\mathrm{SO}_{2}$ with $\mathrm{OH}$ and the source derived from the aqueous transformation rate of $\mathrm{SO}_{2}$ to $\mathrm{SO}_{4}=$ vary strongly with season.

Table 6 compares predicted and observed concentrations of $\mathrm{SO}_{4}=$ at the set of remote locations compiled by Langner and Rodhe (1991) (Table 5 in Langer and Rodhe, 1991). The predicted concentrations appear to be somewhat small in most remote locations except for three regions in the Southern Hemisphere, where concentrations are high due to poor resolution in the model near coastal areas. Table 7 compares predicted and observed deposition of sulfate at remote locations while Figures 6 and 7 compare predicted and observed deposition in the important source areas of North America and Europe. In July, the model slightly overpredicts wet deposition in both source areas, while in January, wet deposition is overpredicted in North America by about a factor of two and underpredicted in Europe by about the same factor. Remote area deposition (shown in Table 7) appears reasonable.

Table 6. Observations and calculated concentrations of nss $\mathrm{SO}_{4}=(\mathrm{ppt})$.

\begin{tabular}{|lcc|}
\hline Location & Observation & Model \\
\hline Northern Hemisphere & & \\
Canadian Arctic & 210 & 24 \\
Spetsbergen & 168 & 100 \\
Bermuda & 455 & 367 \\
Midway & 133 & 86 \\
Oahu & 119 & 112 \\
Barbados & 175 & 141 \\
Guam & 119 & 87 \\
Belau & 147 & 101 \\
Fanning & 154 & 123 \\
& & \\
Southern Hemisphere & & 76 \\
Am. Samoa & 84 & 132 \\
New Caledonia & 98 & 144 \\
Norfolk Island & 56 & 142 \\
Cape Grim & 21 & 25 \\
Mawson & 21 & 6 \\
South Pole & & \\
\hline
\end{tabular}


Table 7. Observed and calculated nss sulfur wet deposition at regional and remote sites $\left(\mathrm{kg} \mathrm{S} \mathrm{km}^{-2} \mathrm{yr}^{-1}\right)$.

\begin{tabular}{|lcc|}
\hline Location & Observation & Model \\
\hline Northem Hemisphere & 32 & \\
Poker Flat, Alaska & 152 & 49 \\
Weathership Lima & 450 & 160 \\
Bermuda & 170 & 326 \\
San Carlos, Venezuela & 150 & 142 \\
East Africa & & 82 \\
& 120 & \\
Southern Hemisphere & 66 & 124 \\
Lake Calado, Brazil & 64 & 63 \\
Am. Samoa & 100 & 33 \\
Katherine, N. Australia & 67 & 49 \\
Amsterdam Island & 37 & 109 \\
New Zealand & 1 & 35 \\
Macquarie Island & 2 \\
South Pole & & \\
\hline
\end{tabular}
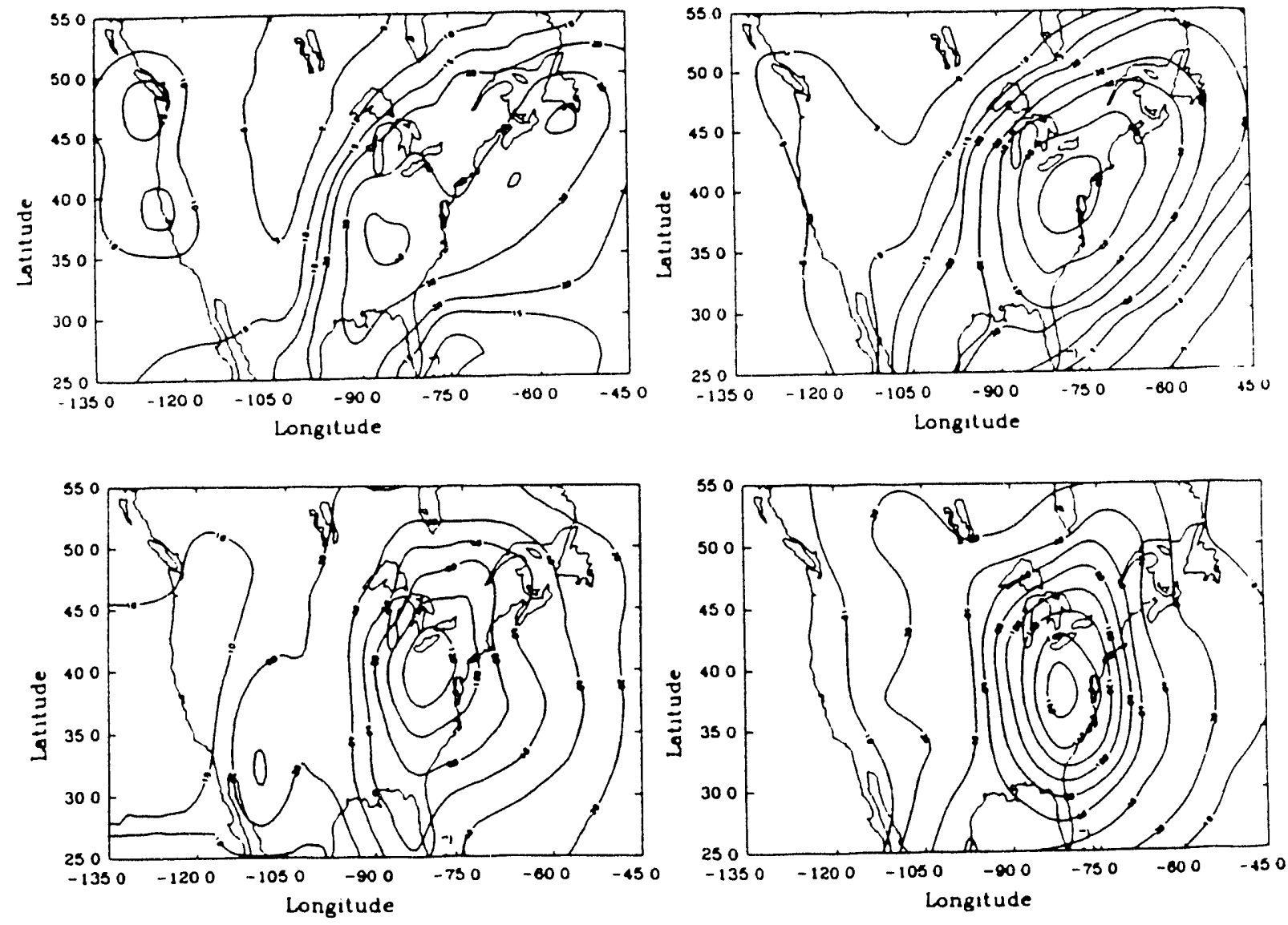

Figure 6. Observed and calculated wet deposition of sulfate over North America. The observations shown are an average from several years of the NADP monthly observations for January and for July for the United States and Canada (Watson and Olsen, 1984). These were averaged and interpolated to the model grid. Panels (a) and (b) show observations (a) and model calculations (b) for January. Contour intervals are 5, 10,15, 20,30,40,60, and $80 \mathrm{~kg} \mathrm{~S} \mathrm{~km}^{-2}$. Panels (c) and (d) show observations (c) and model calculations (d) for July. rontnur intervals are 10. 2n. 40 . $60.80 .1 \mathrm{~m} .12 n$. 140 and $160 \mathrm{ko} . \mathrm{km}^{-2}$ 

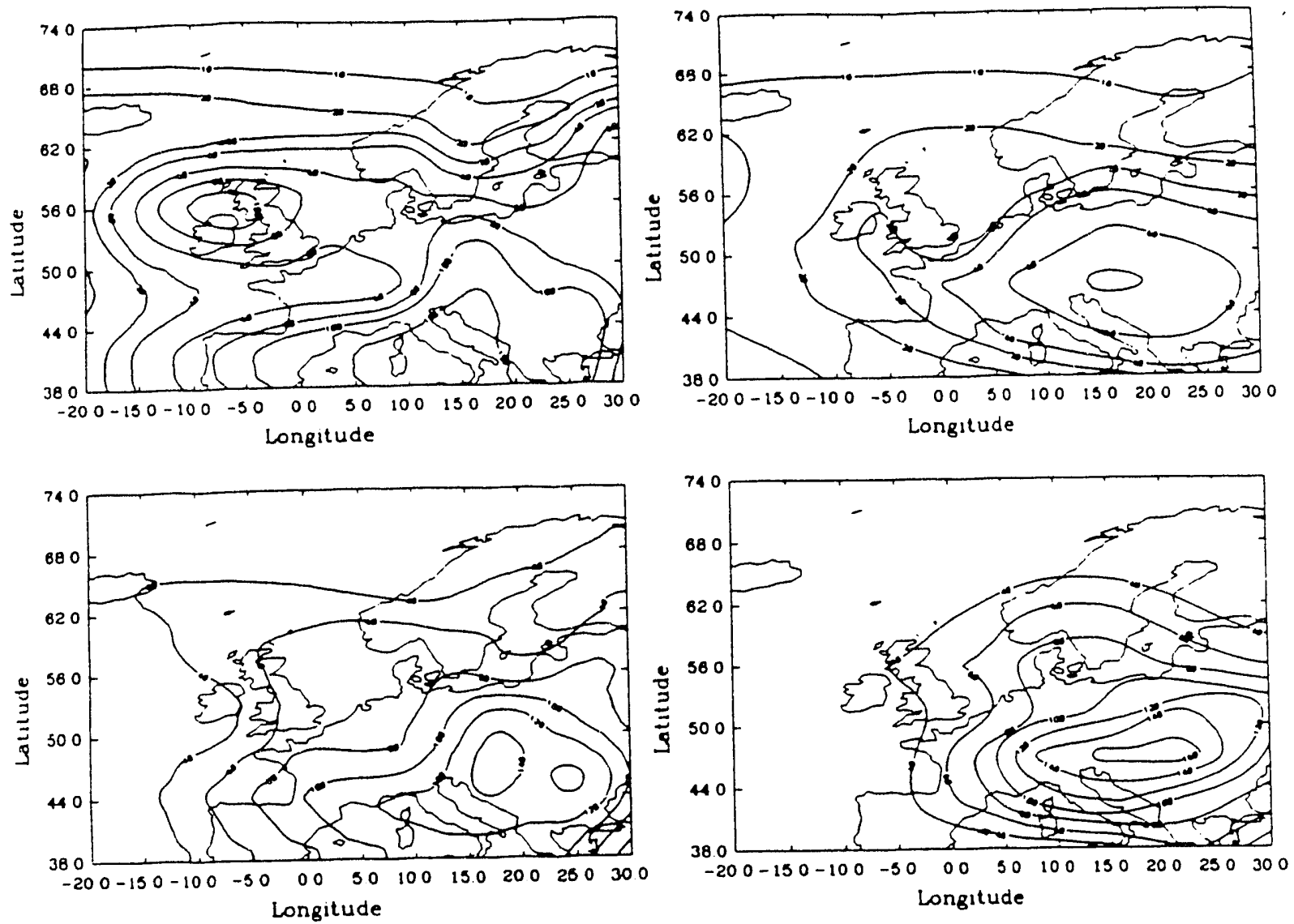

Figure 7. Observed and calculated wet deposition of sulfate over Europe. The observations shown are an average from several years of EMEP monthly observations for January and for July (Jan Schaug, Norwegan Institute of Meteorological Studies, private communication, 1991). These were averaged and interpolated to the model grid. Panels (a) and (b) show observations (a) and model calculations (b) for January. Contour intervals are 10, 20, 30, $40,60,80$, and $100 \mathrm{~kg} \mathrm{~S} \mathrm{~km}^{-2}$. Panels (c) and (d) show observations (c) and model calculations (d) for July. Contour intervals are 40,60,80,100,120,140. and $160 \mathrm{~kg} \mathrm{~S} \mathrm{~km}^{-}$ 2.

The model may be used to assess the relative importance of anthropogenic emissions in determining the concentrations of sulfate aerosol. Figure 8 shows the calculated annual average total sulfate aerosol column abundance, while Figure 9 shows the ratio of the predicted sulfate aerosol column abundance for all sources and for natural sources only. Areas of strong anthropogenic (mainly fossil fuel) emissions in North America, Europe, and Asia clearly stand out while the effects of biomass burning emissions of $\mathrm{SO}_{2}$ are discemable in South America and Africa, even on an annual average basis. We note that the source of (mostly organic) biomass smoke aerosols have not been included in this simulation, but may almost double the anthropogenic aerosol abundance expected in the model (Penner et al., $1991 ; 1992)$. This version of the model is being coupled to a climate model to evaluate the radiative forcing by anthropogenic sulfur emissions (Penner and Taylor, 1993). The climate model predicts a climate forcing from anthropogenic sulfate aerosols (using the 1980 inventories) of approximately $-0.9 \mathrm{Wm}^{-2}$ on an annual average basis. 


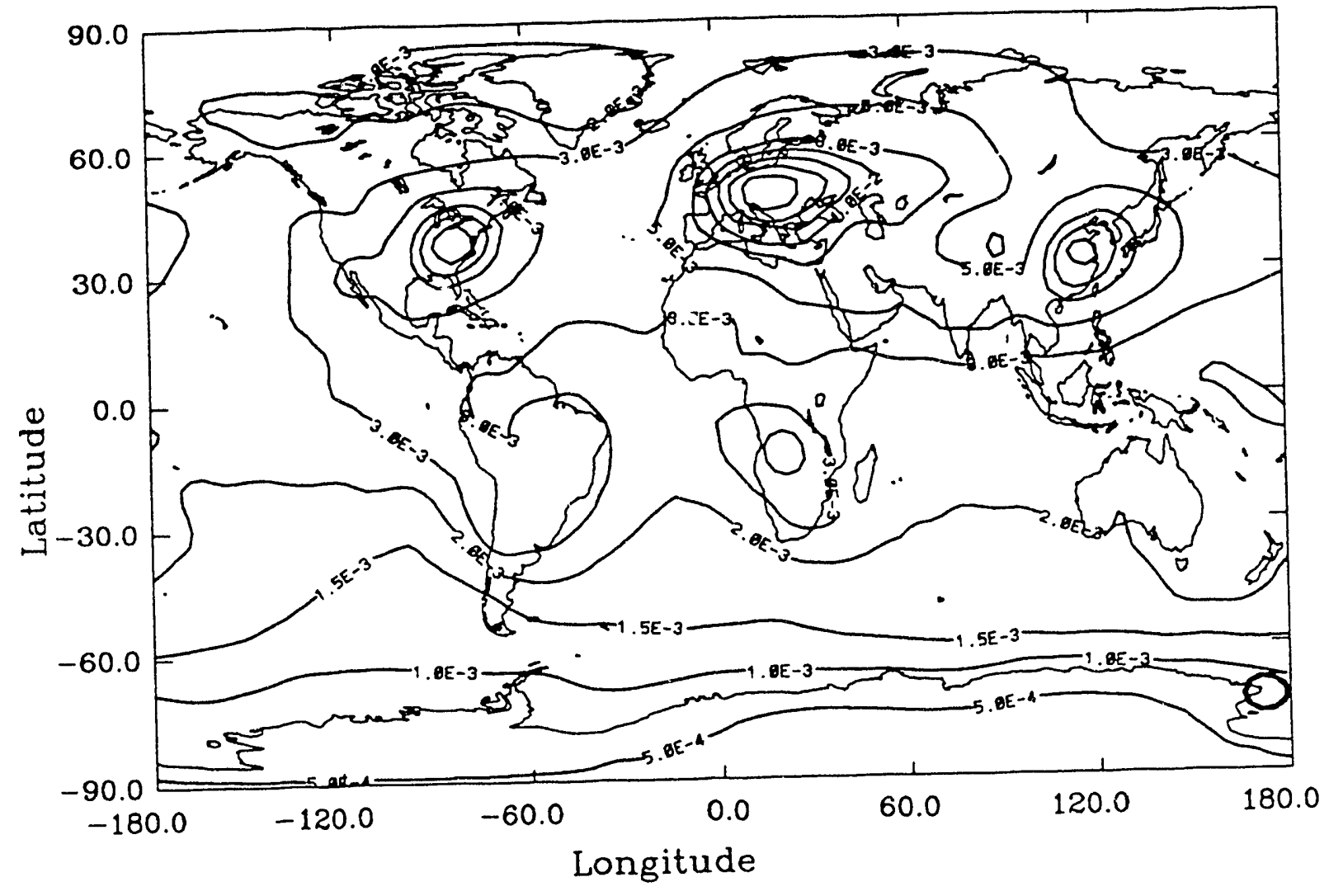

Figure 8. Calculated annual-average column abundance of aerosol sulfate $\left(\mathrm{g} \mathrm{m}^{-2}\right)$. Contour intervals are $5.0 \times 10^{-4}, 1.0 \times 10^{-3}, 1.5 \times 10^{-3}, 2.0 \times 10^{-3}, 3.0 \times 10^{-3}, 5.0 \times 10^{-3}, 8.0 \times 10^{-3}$, $1.0 \times 10^{-2}, 1.2 \times 10^{-2}, 1.4 \times 10^{-2}$, and $1.6 \times 10^{-2} \mathrm{~g} \mathrm{~m}^{-2}$

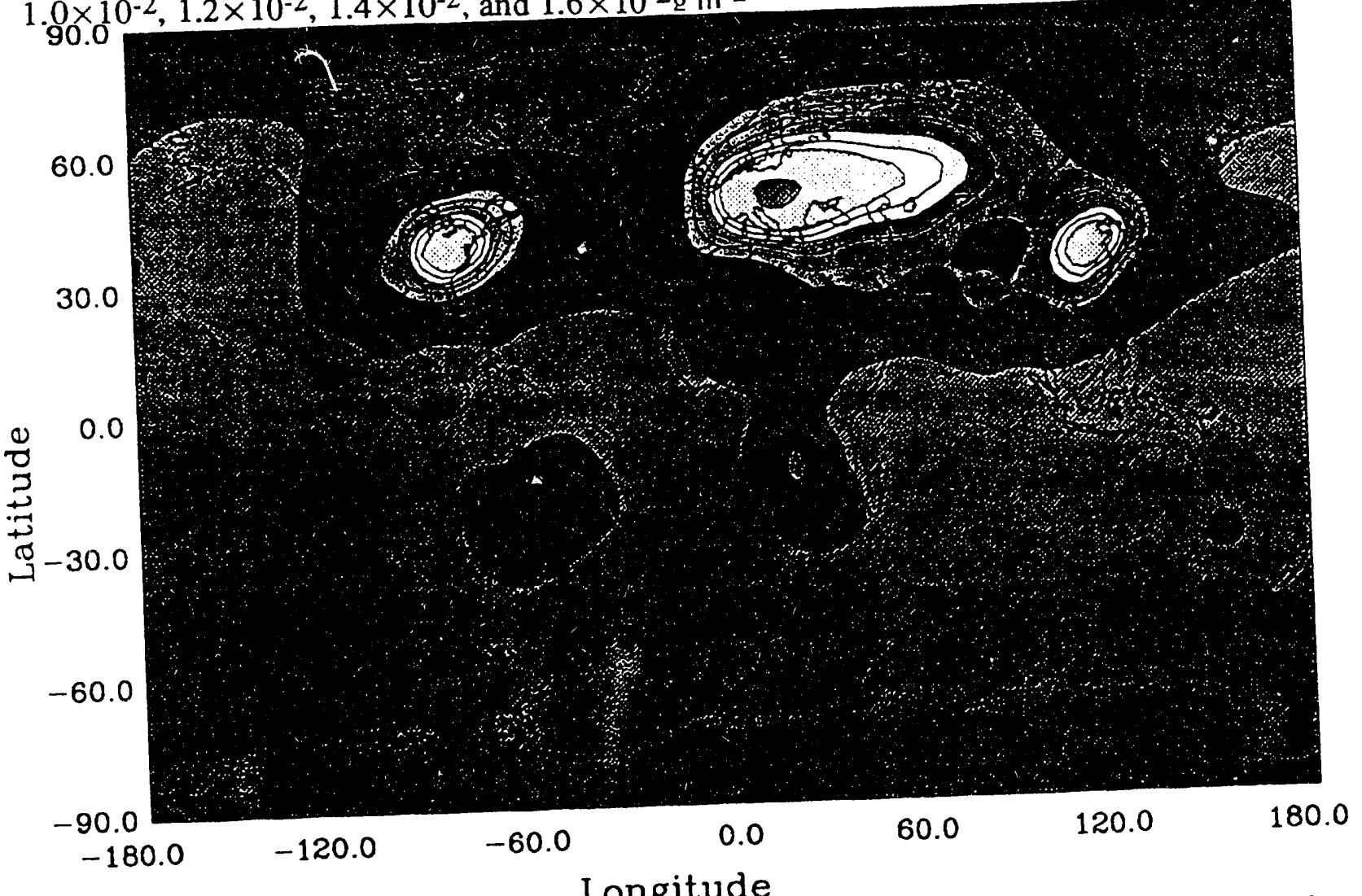

Figure 9. Ratio of the annual-average column abundance of aerosol sulfate for all sources of reactive sulfur (fossil fuel, biomass burning, terrestrial soils, forest, crops, degassing volcanoes and oceans) and for natural sources only (terrestrial soils, forest, crops, degassing volcanoes and oceans). Contour intervals are $2,3,4,5,6,7,8,9,10$, and 15 . 


\section{Model predictions of the efferts of anthropogenic $\mathrm{NO}_{x}$ emissions on $\mathrm{O}_{3}$ and $\mathbf{O H}$}

The formation of $\mathrm{O}_{3}$ in the troposphere results from oxidation of $\mathrm{CO}, \mathrm{CH}_{4}$, and nonmethane hydrocarbons (NMHC's) in the presence of $\mathrm{NO}_{\mathbf{x}}$ and sunlight. As noted above, we have fixed the concentrations of $\mathrm{CO}$ and $\mathrm{CH}_{4}$ in the present model while NMHCs are not yet included. Model calculations of the tropospheric $\mathrm{O}_{3}$ and $\mathrm{OH}$ abundance require reactive nitrogen emissions from five main sources: fossil fuel combustion, biomass burning (including wood fuel burning), soil microbial activity, lightning discharges, and production of reactive nitrogen in the stratosphere by reaction of $\mathrm{O}\left({ }^{1} D\right)$ with $\mathrm{N}_{2} \mathrm{O}$. A separate category of fossil fuel emissions from aircraft is considered because of its injection at high altitude. Table 10 gives a summary of the magnitude of the reactive nitrogen sources that were used in the calculations reported here. Also shown are the range in possible emissions magnitudes as reported by a number of authors (see Penner, 1993).

Table 10. Sources of reactive nitrogen ( $\mathrm{Tg} \mathrm{N} / \mathrm{yr})$.

\begin{tabular}{|l|c|c|}
\hline \multicolumn{1}{|c|}{ Source } & Total & Range \\
\hline Anthropogenic & & \\
Fossil fuel burning & 22.4 & $15-25$ \\
Biomass burning (land clearing) & 13 & $2-20$ \\
Aircraft emissions & 0.23 & $0.1-0.7$ \\
Wood burning & 0.2 & $0.1-0.8$ \\
& & \\
Natural & 5 & $1-20$ \\
Soil microbial emissions & 10 & $2-100$ \\
Lightning discharge & 1.0 & $0.5-1.5$ \\
Production in the stratosphere & 51.8 & $20-168$ \\
\hline
\end{tabular}

The emissions from fossil fuel combustion used the inventory developed by Dignon (1992) except where updated according to the GEIA inventories noted above. The emissions from biomass burning used the amount of biomass burned on monthly biomass compiled by Hao et al. (1989) for Central and South America, Tropical Africa and Tropical Asia. Additional information on Australian biomass burning was compiled by Dignon (personal communication, 1992). We assumed emission factors of $2.5 \mathrm{gN} / \mathrm{kg}$ dry matter) for forest burning and $1.9 \mathrm{gN} / \mathrm{kg}$ dry matter) for Savanna burning based on the analysis of fuel nitrogen published by Dignon and Penner (1991). The aircraft source was injected on an annual average basis and used a 1989 inventory compiled by the Warren Spring Laboratory (1989). This source was distributed between $\mathbf{X X}$ and $\mathbf{x x}$ mb according to prevailing flight corridors and altitudes.

The natural sources of reactive nitrogen were each varied on a monthly basis. The total annual $\mathrm{NO}_{\mathrm{x}}$ emission for cloud to cloud and cloud to ground lightning discharges was adjusted to $10 \mathrm{Tg} / \mathrm{yr}$ based on previous analysis and fitting to observed nitrate deposition and nitric acid concentrations (Atherton et al., 1991). The distribution of source intensity was based on observed thunderdays (Handbook of Geophysics, 1960) and used the methodology

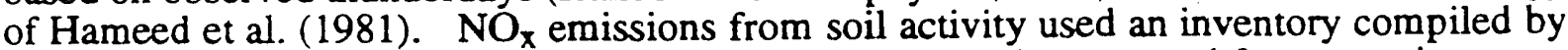
Dignon et al. (1991) and were based on relationships which accounted for vegetation type, soil moisture and soil temperature.

The adequacy of the current model may be judged by comparison of model predictions with measurements of air concentration and wet deposition. Comparisons for nitrogen are similar to those made previously (Penner et al., 1991). Recent observations of nitrogen compounds, however, provide support for a substantial fractional abundance of PAN (summarize!!) which is not calculated in the current simulation. Future simulations 
which include nonmethane hydrocarbon sources will allow a more robust calculation of the nitrogen cycle.

Calculations for $\mathrm{O}_{3}$ may be compared to monthly mean surface concentrations and to $\mathrm{O}_{3}$ profiles compiled by the NOAA Climate Monitoring and Diagnostics Laboratory (Oltmans, personal communication, 1993; Oltmans and Levy, 1993; Komhyr et al., 1989). Figure 10 compares the predicted monthly mean surface $\mathrm{O}_{3}$ concentration to data from Mauna Loa $(20 \mathrm{~N}, 156 \mathrm{~W})$, Izania $(28 \mathrm{~N}, 17 \mathrm{~W})$, Mace Head (53N. 10W), Niwot Ridge (40N, $157 \mathrm{~W})$, Barbados (13N, 60W), Bermuda (32N, 65W), Reykjavik (64N, 22W), Barrow (71N, 157W), Samoa (14S, 171W) and the South Pole (90S, 102E). At four of the sites (Barbados, Bermuda, Reykjavik and Mace Head) the agreement for both total abundance and seasonal cycle is quite good. However, at five sites (Mauna Loa, Izania, Niwot Ridge, Samoa, and the South Pole), model values are lower than observations by $5-20$ ppbv. The lack of agreement may be partly due to dynamics (model predictions at Barrow, for example, are poor in spring--even for species which do not undergo photochemical processing--see, for example, Penner et al., 1993). Part of the underprediction, however, may be caused by the fact that the current model does not treat NMHCs and the resulting production of PAN.
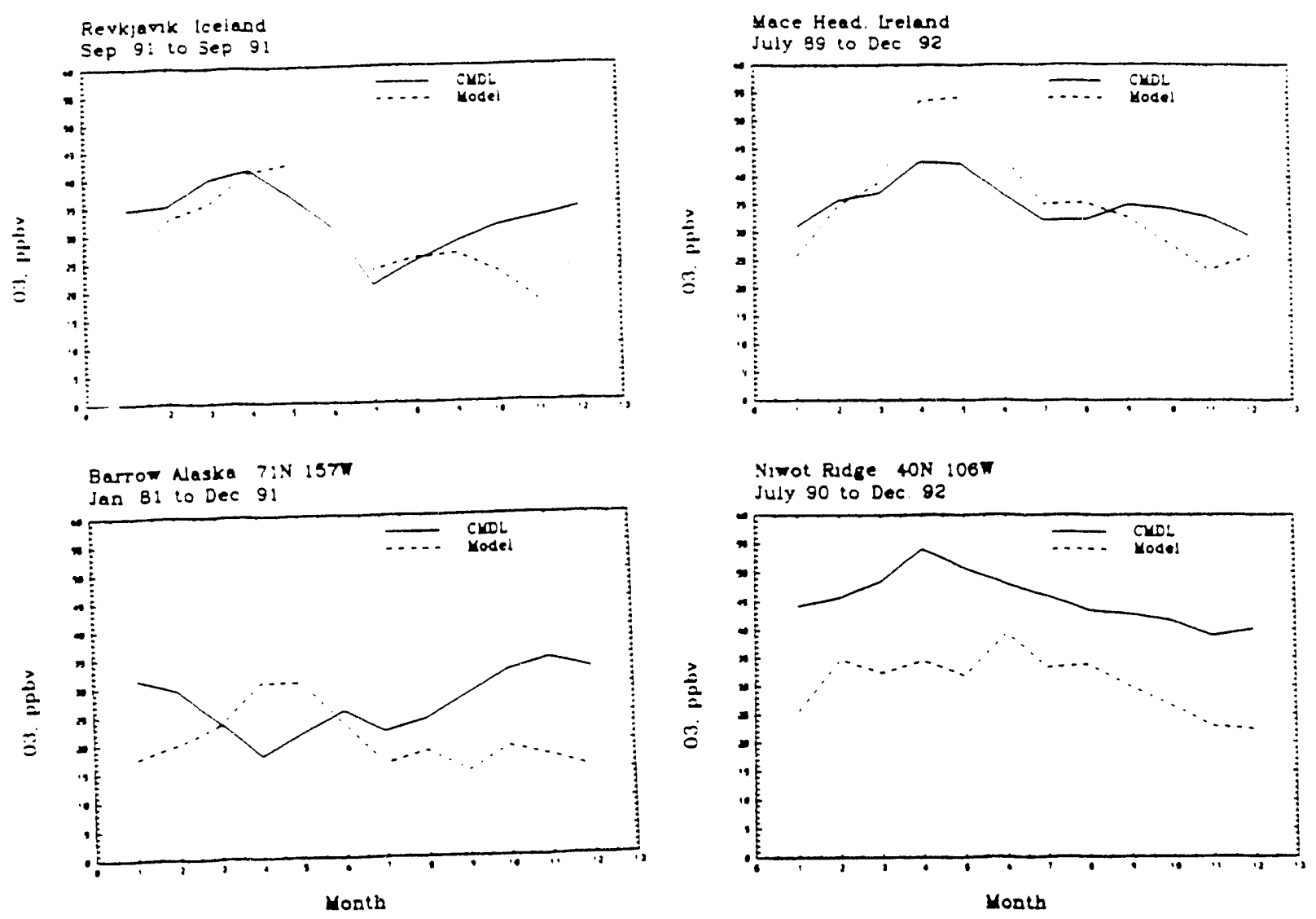

Figure 10. Observed (solid line) and calculated (dashed line) monthly mean ozone concentrations at the surface at Mauna Loa, Izania, Mace Head, Niwot Ridge, Barbados, Bermuda, Reykjavik, and Barrow. Observations are from the NOAA Climate Monitoring and Diagnostics Laboratory (S. Oltmans, private communication. 1993). 

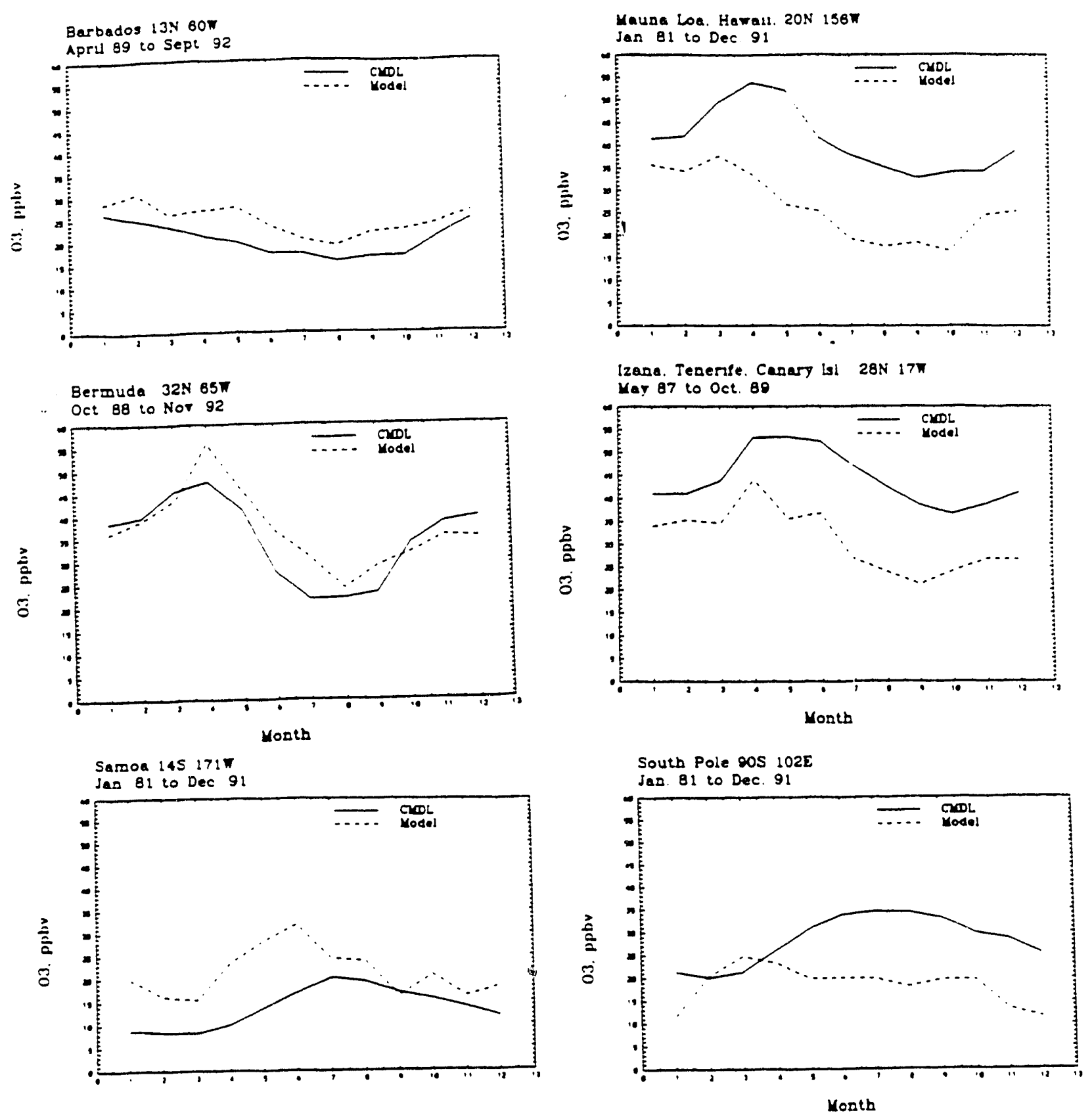

Figure 10. (continued). Observed (solid line) and calculated (dashed line) monthly mean ozone concentrations at the surface at Samoa, and the South Pole. Observations are from the NOAA Climate Monitoring and Diagnostics Laboratory (S. Oltmans, private communication. 1993).

Model predicted profiles of $\mathrm{O}_{3}$ partial pressures are compared to ozonesonde observations in Figures $11 \mathrm{a}$ and $11 \mathrm{~b}$. Figures $11 \mathrm{a}$ and $11 \mathrm{~b}$ show the annual average observed and model predicted profiles between the surface and 100 mbars at five Northern Hemisphere sites (Hilo (9N, 155W), Boulder (40N, 105W), Edmonton (53N, 114W), Barrow $(71 \mathrm{~N}, 157 \mathrm{~W})$ and Resolute $(74 \mathrm{~N}, 95 \mathrm{~W}))$ and at four Southern Hemisphere sites (Samoa (14S, 170W), Lauder (45S, 170E), Syowa $(69 S, 39 E)$ and South Pole (90S, $25 W)$ ). Values in the top 100 mbars are fixed equal to the measured concentrations. The increase in $\mathrm{O}_{3}$ with latitude is captured by the model, but overall, predicted concentrations are low. In the Southern Hemisphere, NMHCs will not play as great a role as they do in the Northem Hemisphere. Here, the predicted abundances agree reasonably well with measured partial pressures. 

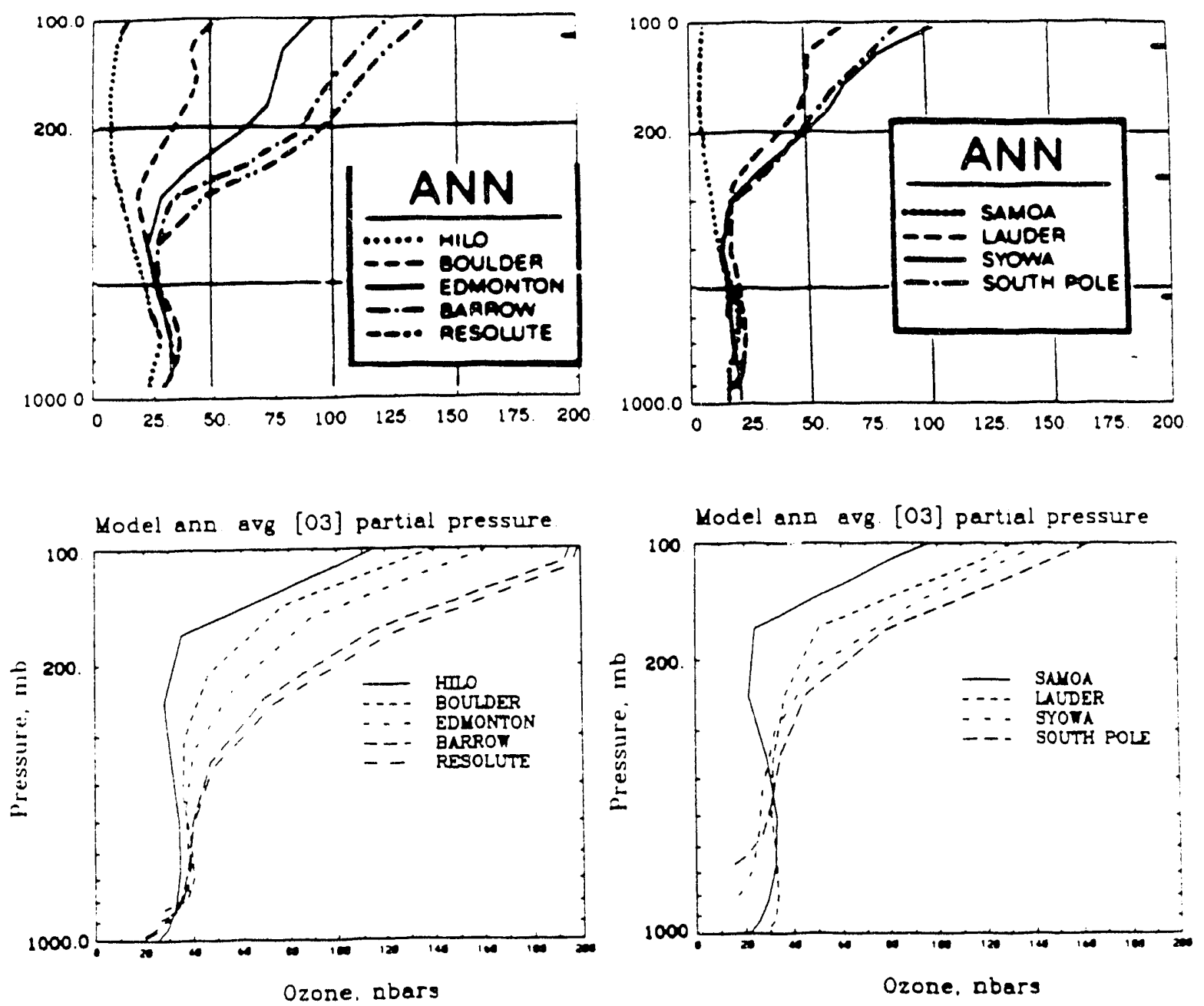

Figure 11. Observed (a) and calculated (b) tropospheric ozone partial pressures as a function of altitude at Hilo $(9 \mathrm{~N}, 155 \mathrm{~W})$, Boulder $(40 \mathrm{~N}, 105 \mathrm{~W})$, Edmonton (53N, 114W), Barrow $(71 \mathrm{~N}, 157 \mathrm{~W})$ and Resolute $(74 \mathrm{~N}, 95 \mathrm{~W})$ for the Northern Hemisphere and at Samoa (14S, $170 \mathrm{~W})$, Lauder (45S, 170E), Syowa (69S, 39E) and South Pole (90S, 25W) for the Southern Hemisphere. The observations are from Komyhr et al. (1989).

The relative importance of anthropogenic $\mathrm{NO}_{x}$ emissions to surface $\mathrm{O}_{3}$ and $\mathrm{OH}$ concentrations is shown in Figures 12 and 13. Figure $12 \mathrm{a}$ and $13 \mathrm{a}$, respectively, show $\mathrm{O}_{3}$ and $\mathrm{OH}$ concentrations for July with all sources of reactive nitrogen included in the simulation while Figures $12 \mathrm{~b}$ and $13 \mathrm{~b}$ show the results when only natural sources are included. As indicated there, concentrations of $\mathrm{O}_{3}$ increase by between 20 to $40 \mathrm{ppb}$ over Europe ppb and by similar amounts over the United States. Concentrations of tropospheric $\mathrm{OH}$ increase as well, from average concentrations near $1.7 \times 10^{6} \mathrm{~cm}^{-3}$ and $8.0 \times 10^{5} \mathrm{~cm}^{-3}$ for the Northern Hemisphere and Southern Hemisphere, respectively, in July for natural sources only to concentrations of $1.9 \times 10^{6} \mathrm{~cm}^{-3}$ and $8.7 \times 10^{5} \mathrm{~cm}^{-3}$, respectively, for July when all sources of reactive nitrogen are included. Figure 14 indicates that larger changes occur near the source regions.

\section{Conclusions}

Accurate emissions inventories are a crucial element in the further advancement of three-dimensional photochemical models. These emissions, when combined with models may be used to check the accuracy of our understanding of photochemical processes, transport, transformation, and removal. Comparison of the models with data show a number of similar features, but differences point to the need for improved models. It is important to further develop our understanding of emissions inventories (both natural and anthropogenic) 
because the models have demonstrated important changes to both sulfate aerosol and to $\mathrm{O}_{3}$ and $\mathrm{OH}$ fields as a result of anthropogenic emissions.

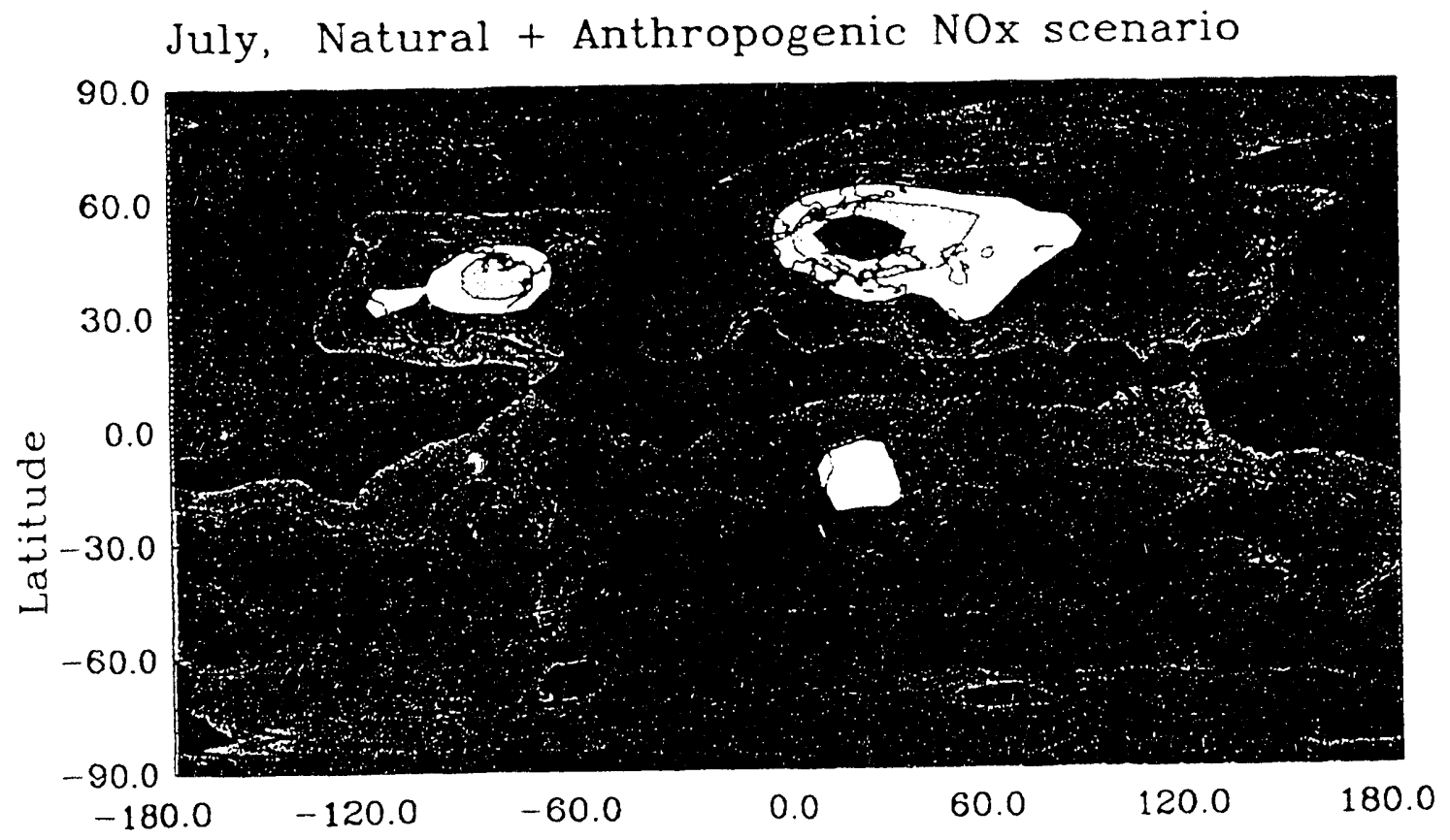

July, Natural NOx ONLY scenario
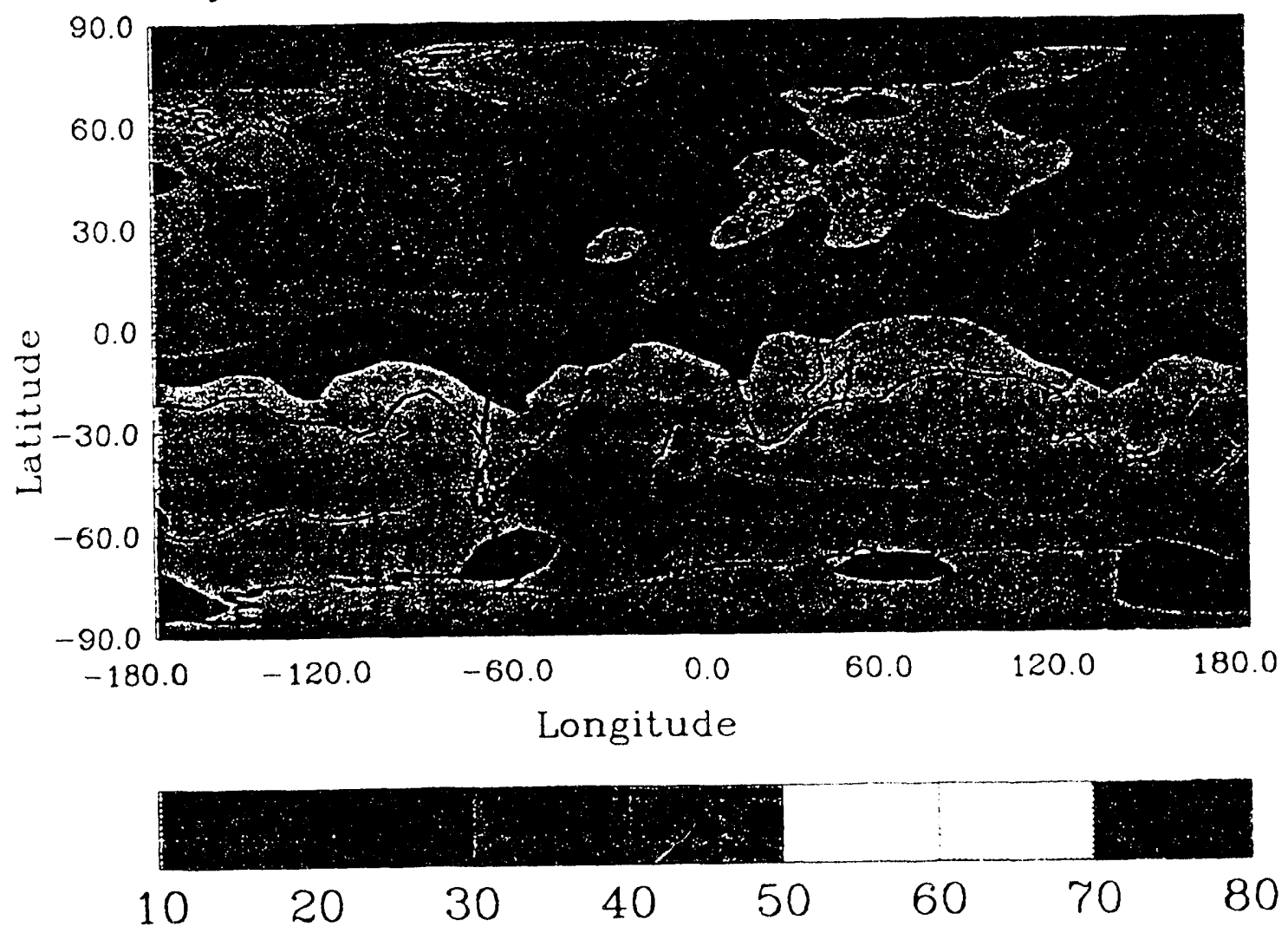

Figure 12. Calculated ozone concentrations at the surface in July with all sources of reactive nitrogen emissions included (panel a) and with only natural sources included (panel b). 

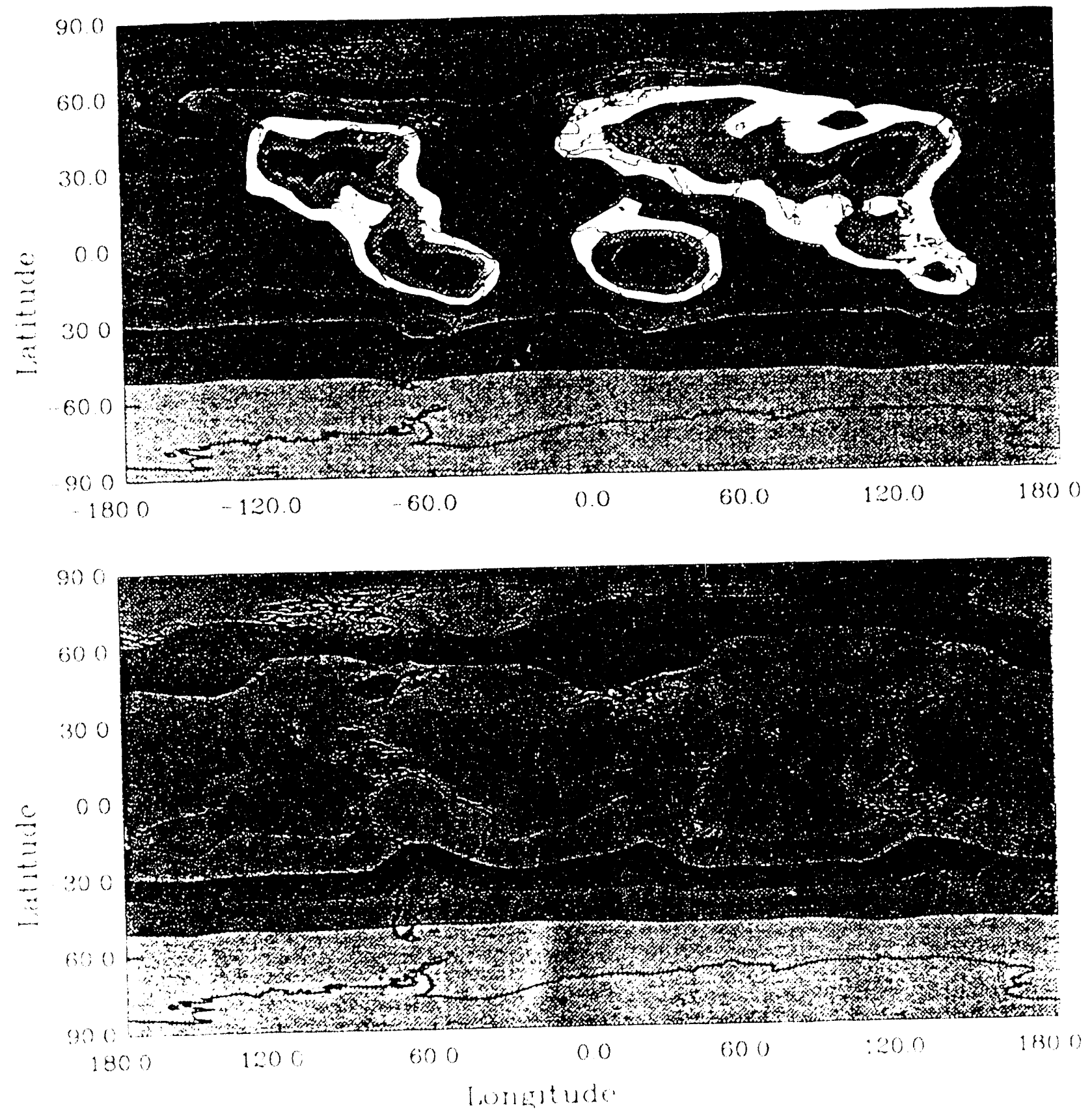

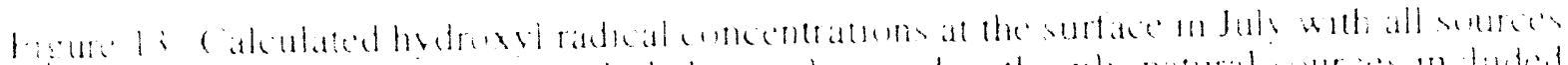
a) l.inel t:1

\section{v1. Acknowledgements}

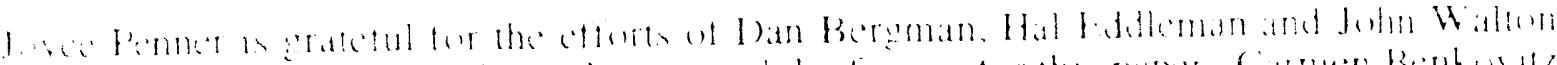

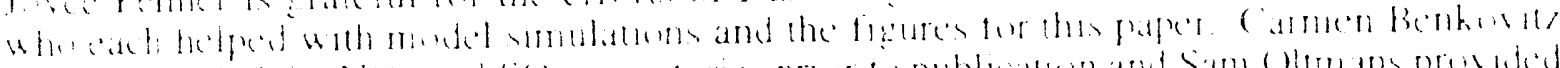

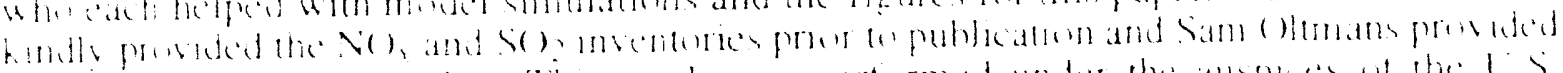

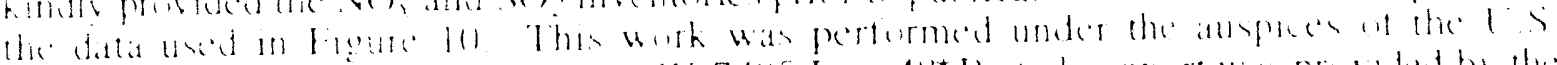

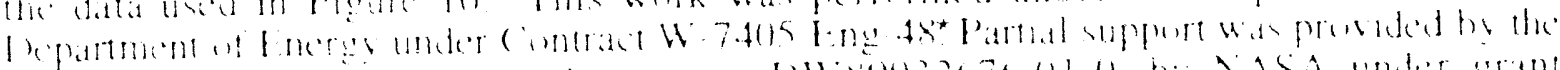

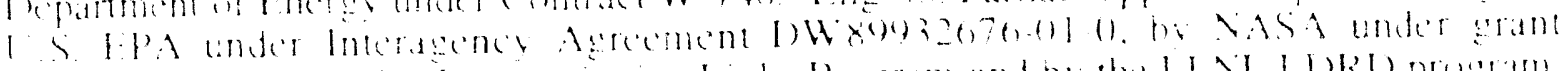

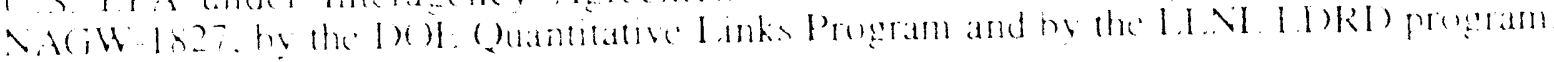


Atherton, C.S., 1993: Thesis, University of California, Davis, in preparation.

Atkinson, R., D.L. Baulch, R.A. Cox, R.F. Hampson Jr., J.A. Kerr, and J. Troe, 1992: Evaluated kinetic and photochemical data for atmospheric chemistry: Supplement IV, Atrios. Environ., 26A, 1187-1230.

Carnovale, F., 1992: private communication, Australian Environment Protection Authority.

Covey, C., S. J. Ghan, J. J. Walton and P. R. Weissman, 1990: Global environmental eifects of impact-generated aerosols: Results from a general circulation model, in Global Catastrophes in Earth History: An Interdisciplinary Conference on Impacts, Volcanism and Mass Mortality, V.L. Sharpton and P.D. Ward (Eds.), Geological Society of America, Boulder, Colo., 263-270.

Crutzen and Zimmerman, 1991: The changing photochemistry of the troposphere, Tellus, 43AB, $136-151$.

DeMore, W. B., S. P. Sander, D.M. Golden, R.F. Hampson, M.J. Kurylo, C.J. Howard, A.R. Ravishankara, C.E. Kolb, and M.J. Molina, 1992: Chemical kinetics and photochemical data for use in stratospheric modeling, Jet Propulsion Laboratory California Institute of Technology Publication 92-20.

Dignon, J. and S. Hameed, 1985: Global emissions of nitrogen and sulfur oxides from 1860 to 1980, J. Air Poll. Con. Assoc., 39, 180-186.

Dignon, J., and J.E. Penner, 1991: Biomass burning: A source of nitrogen oxides in the atmosphere, in Global Biomass Burning, ed. by J. Levine, MTT press, Cambridge, MA. 370-3\%5.

Dignon, J., 1992: $\mathrm{NO}_{\mathrm{x}}$ and $\mathrm{SO}_{\mathrm{x}}$ emissions from fossil fuels: A global distribution, Atmos. Environ., 26A, 1 is $57-i 163$.

Dignon, J., J.E. Penner, and J. J. Walton, 1993: Simulation of ${ }^{222} \mathrm{Rn}$ and $210 \mathrm{~Pb}$ in a threedimensional chemical transport modei, in preparation.

Erickson III, D.J., J.J. Waiton, S.J. Ghan, and J.E. Penner, 1991: Three-dimensional modeling of the global atmospheric sulfur cycle: A first step, Atmos. Environ., 25A, $2513-2520$.

Fishman, J., V. Ramanathan, P.J. Crutzen, and S. C. Liu, 1979: Tropospheric ozone and climate, Nature, 282, 818-820.

Galloway, J.N., J.E. Penner, C.S. Atherton, D.R. Hastie, J.M. Prospero, H. Rodhe, R.S. Artz, Y.J., Balkanski, H.G. Bingemer, R.A. Brost, S. Burgermeister, G.R. Carmichael, J.S. Chang, R.J. Charlson, S. Cober, W.G. Ellis Jr., C.J. Fischer, J.M Hales, T. Iversen, D.J. Jacob, K. John, J.E. Johnson, P.S. Kasibhatla, J. Langner, J. Lelieveld, H. Levy II, F. Lipschutz, J.T. Merrill, A.F. Michaels, J.M. Miller, J.L. Moody, J. Pinto, A.A.P. Pzenny, P.A. Spiro, L. Tarrason, S.M. Turner, and D.M. Whelpdale, 1992: Sulfur and nitrogen levels in the North Atlantic Ocean's atmosphere: A synthesis of field and modeling results, Global Biogeochemical Cycles, 6, 77-100.

Ghan, S. J., M. C. MacCracken, and J. J. Walton, 1988: Climat response to large atmospheric smoke injections: Sensitivity studies with a tropospheric general circulation model, J. Geophys. Res., 93, 8315-8337.

Johnston, H.S., D.E. Kunnison, and D.J. Wuebubles, 1989: Nitrogen oxides from highaltitude aircraft: An update of potential effects on ozone, J. Geophys. Res., 94, $16351-16363$. 
Kato, N. and H. Akimoto, 1992: Anthropogenic emissions of $20_{2}$ and $\mathrm{NO}_{\mathrm{x}}$ in Asia: Emissions inventories, Atmos. Environ., 26A, 2997-3017.

Kato, N. and H. Akimoto, 1993: Errata, Atmos. Environ., in press.

Komyhr, W.D., S.J. Oltmans, P.R. Francois, W.F.J. Evans, and W.A. Matthews, The latitudinal distribution of ozone to $35 \mathrm{~km}$ altitude from ECC ozonesonde observations, in: Ozone in the Atmosphere, edited by R.D. Bojkov and P. Fabian, A. Deepak Publishing, Hampton, Va., 147-150.

Langner, J. and H. Rodhe, 1991: A global three-dimensional model of the tropospheric sulfur cycle, Tellus, 13, 225-264.

Lelieveld, J., and Crutzen, P.J., 1990: Influences of cloud photochemical processes on tropospheric ozone, Nature, 343, 227-233.

Lelieveld, J., and P.J. Crutzen, 1991: The role of clouds in tropospheric photochemistry, $J$. Atmos. Chemi., 12, 229-267.

Oltmans, S. and H. Levy II, 1993:

Pacyna, J., 1992: Point source emissions of $\mathrm{SO}_{2}$ and $\mathrm{NO}_{\mathrm{x}}$ in the Asian part of the former USSR, Norwegian Institue for Air Research.

Penner, J.E., 1990: Cloud albedo, greenhouse effects, atmospheric chemistry and climate change, J. of the Air and Waste Management Assoc., 40, 456-461.

Penner, J.E., C.S. Atherton, J. Dignon, S.J. Ghan, J.J. Walton, and S. Hameed, 1991: Tropospheric nitrogen: A three-dimensional study of sources, distribution, and deposition, J. of Geophys. Res., 96, 959-990.

Penner, J.E., S.J. Ghan, and J.J. Walton, 1991: The role of biomass burning in the budget and cycle of carbonaceous soot aerosols and their climate impact, in Global Biomass Burning, ed. by J. Levine, MIT press, Cambridge, MA, 387-393.

Penner, J.E., R. Dickinson and C. O'Neill, 1992: Effects of aerosol from biomass burning on the global radiation budget, Science, 256, 1432-1434.

Penner, J.E. 1993: The role of human activity and land use change in atmospheric chemistry and air quality, in the Proceedings of the 1991 Global Change Institute on Global Land Use/Cover Change, edited by B. Tumer, in press.

Penner, J.E., H. Eddleman and T. Novakov, 1993: Towards the development of a global inventory of black carbc a emissions, Atmos. Environ., in press.

Penner, J.E., R.J. Charlson, J.M. Hales, N. Laulainen, R. Leifer, T. Novakov, J. Ogren, L.F. Radke, S.E. Schwartz, and L. Travis, 1993: Quantifying and minimizing uncertainty of climate forcing by anthropogenic aerosols, submitted to the Bulletin of the American Meteorological Society.

Penner, J.E. and K. Taylor, 1993: Aerosols, atmospheric chemistry and climate: The need for coupled simulations, presented at the CHAMMP Science Team Meeting, March 1517, 1993, Monterey, California.

Sandnes, H. and H. Styve, 1992: Calculated budgets for airborne acidifying components in Europe, 1985, 1986, 1987, 1988, 1989, 1990 and 1991, Meteorological Synthesizing Centre-West, The Norwegian Meteorological Institute. EMEP/MSC-W 1/92, Oslo, Norway. 
Saeger, M., J. Langstaff, R. Walters, L. Modica, D. Zimmerman, D. Fratt, D. Dulleba, R. Ryan, J. Demmy, W. Tax, D. Sprague, D. Mudgett and A.S. Wernerk, 1989: The 1985 NAPAP emissions inventory (version 2): Development of the annual data and modelers' tapes, U.S. Environmental P\{rotection Agency, EPA-600/7-89-012a, Washington, D.C.

Spiro, P.A., D.J. Jacob, and J.A. Logan, 1992: Global inventory of sulfur emissions with $1^{\circ} \times 1^{\circ}$ resolution," J. of Geophys. Res, 97, 6023-6036.

Taylor, K., and J.E. Penner, 1993: Climate model simulation of the effects of sulfate aerosol on temperature, in preparation.

Tilton, B.E., 1989: Health effects of tropospheric ozone, Environ. Sci. Technol., 23, 257 263.

Wagner, J., R.A. Walters, L.J. Maiocco and D.R. Neal, 1986: Development of the 1980 NAPAP emissions inventory, Environmental Protection Agency, EPA-600/7-86-057a, Washington, D.C.

Walton, J. J., M. C. MacCracken and S. J. Ghan, 1988: A global-scale Lagrangian trace species model of transport, transformation, and removal processes, J. Geophys. Res., 93, 8339-8354.

Watson, C.R. and A.R. Olsen, Acid deposition system (ADS) for statistical reporting: System design and user's code manual, Rep. EPA-600/8-84-023, U.S. Environ. Prot. Agency, Research Triangle Park, N.C.

Wuebbles, D.J., D.E. Kinnison, 1989: A two-dimensional model study of past trends in global ozone, in Ozone in the Atmosphere, edited by R.D. Bojkov and P. Fabian, A. Deepak Publishing.

Wuebbles, D.J. D.E. Kinnison, K.E. Grant, and P.S. Connell, 1993: Effects of the Mt. Pinatubo eruption on the chemistry, radiative and transport processes in the stratosphere, proceedings of the Conference on Atmospheric Chemistry, American Meteorological Society, held January 17-22, 1993, in Anaheim, California, 1-8. 

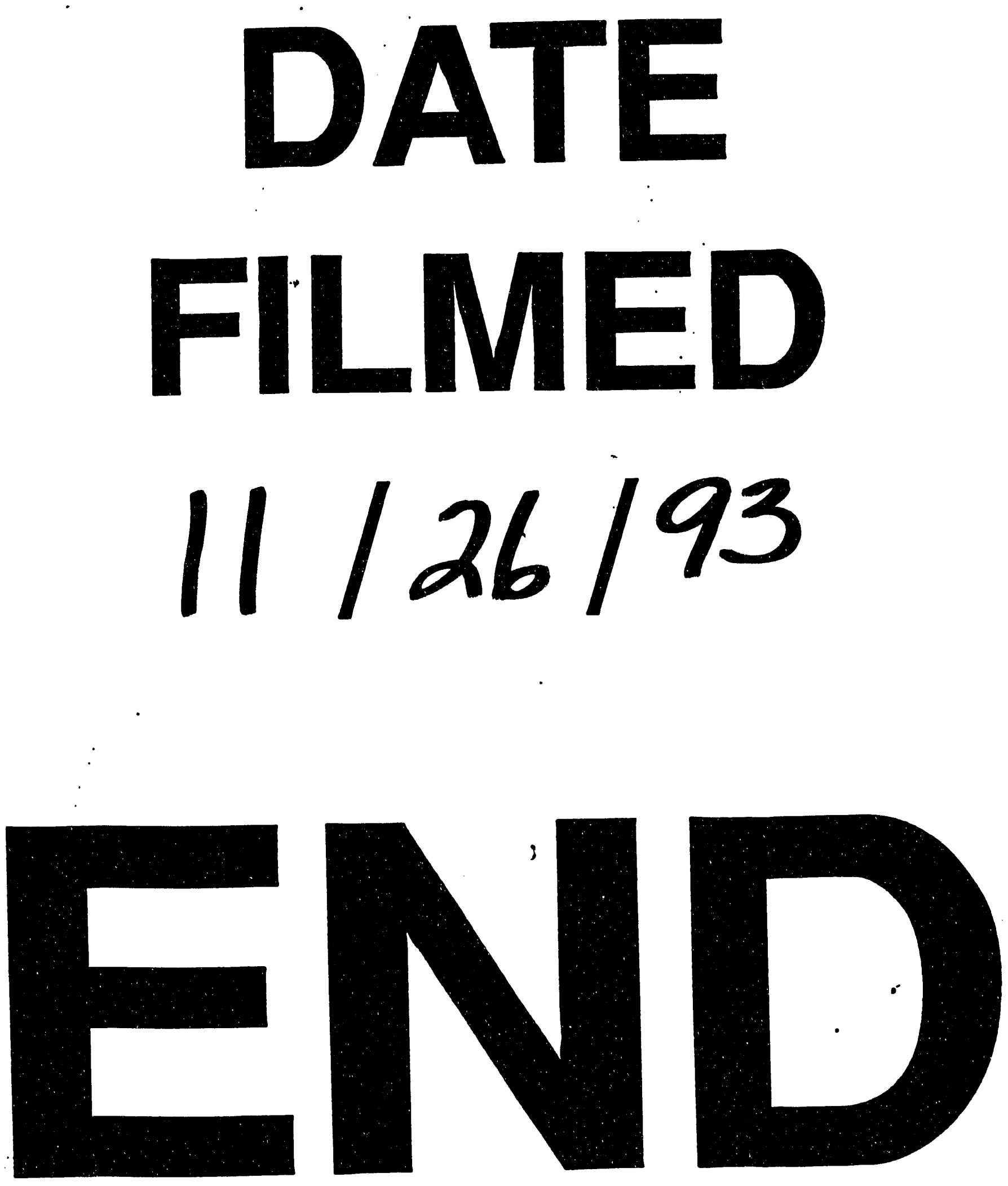
